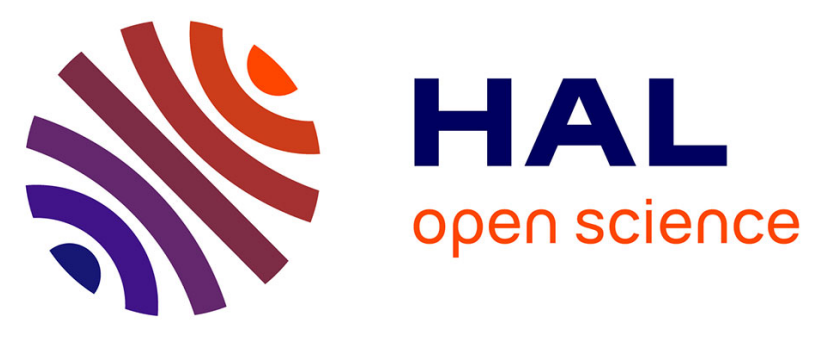

\title{
Evolution of calc-alkaline to alkaline magmatism through Carboniferous convergence to Permian transcurrent tectonics, western Chinese Tianshan
}

Bo Wang, Dominique Cluzel, Liangshu S. Shu, Michel Faure, Jacques

Charvet, Yan Chen, Sébastien Meffre, Koenraad de Jong

\section{To cite this version:}

Bo Wang, Dominique Cluzel, Liangshu S. Shu, Michel Faure, Jacques Charvet, et al.. Evolution of calc-alkaline to alkaline magmatism through Carboniferous convergence to Permian transcurrent tectonics, western Chinese Tianshan. International Journal of Earth Sciences, 2009, 98 (6), pp.12751298. 10.1007/s00531-008-0408-y . insu-00357021

\section{HAL Id: insu-00357021 \\ https://hal-insu.archives-ouvertes.fr/insu-00357021}

Submitted on 5 Feb 2009

HAL is a multi-disciplinary open access archive for the deposit and dissemination of scientific research documents, whether they are published or not. The documents may come from teaching and research institutions in France or abroad, or from public or private research centers.
L'archive ouverte pluridisciplinaire HAL, est destinée au dépôt et à la diffusion de documents scientifiques de niveau recherche, publiés ou non, émanant des établissements d'enseignement et de recherche français ou étrangers, des laboratoires publics ou privés. 


\title{
Evolution of calc-alkaline to alkaline magmatism through Carboniferous convergence to Permian transcurrent tectonics, western Chinese Tianshan
}

Bo Wang ${ }^{1,2,3}$, Dominique Cluzel ${ }^{2}$, Liangshu Shu ${ }^{1}$, Michel Faure ${ }^{2}$, Jacques Charvet ${ }^{2}$, Yan Chen ${ }^{2}$, Sebastien Meffre ${ }^{4}$ and Koen de Jong ${ }^{2}$

(1) State Key Laboratory for Mineral Deposits Research, Department of Earth Sciences, Nanjing University, 210093 Nanjing, China

(2) ISTO UMR 6113, University of Orléans, 45067 Orléans, Cedex 2, France

(3) Institute of Earth Sciences, Academia Sinica, Taipei, 11529, Taiwan, ROC

(4) School of Earth Sciences, University of Tasmania, Hobart, Australia

\begin{abstract}
Continuous magmatic activity occurred in the western Chinese Tianshan, Central Asia, from the Carboniferous to the Permian, i.e. before and after the Late Carboniferous amalgamation of Junggar and the Yili Blocks. Zircon U-Pb LA-ICPMS and Ar-Ar data reveal a coincidence in time between regional wrench faulting and granitoid emplacement. Permian post-collisional granitoids crop out within or at the margins of large-scale dextral strike-slip shear zones, some of them show synkinematic fabrics. The whole rock geochemical features of the Early-Middle Permian granitoids indicate an evolution from high$\mathrm{K}$ calc-alkaline towards alkaline series. In other places of the North Tianshan, alkaline magmatism occurred together with deep marine sedimentation within elongated troughs controlled by wrench faults. Therefore, in contrast with previous interpretations that forwarded continental rift or mantle plume hypotheses, the coexistence of diverse magmatic sources during the same tectonic episode suggests that post-collisional lithosphere-scale transcurrent shearing tightly controlled the magmatic activity during the transition from convergent margin to intraplate anorogenic processes.
\end{abstract}

Keywords Granitoids - Zircon U-Pb geochronology - Geochemistry - Transcurrent shear zones - Late Palaeozoic - Chinese Tianshan

\section{Introduction}

The tectonic assemblage of the Central Asian Orogenic Belt was suggested to occur during Palaeozoic time by the closure of Paleoasian Ocean and multi-phase subduction-accretion of various micro-continents, ancient island arcs and fragments of oceanic island (Coleman 1989; Dobretsov et al. 1995; Jahn et al. 2000, 2004; Jahn 2004; Xiao et al. 2004; Windley et al. 2007).

The Chinese Tianshan Belt which is a part of this orogenic belt, separates the Tarim Basin to the south from the Junggar Basin to the north (Fig. 1). Classically, it is considered that the western Chinese Tianshan (west of Meridian $88^{\circ} \mathrm{E}$; Fig. 1) was built by two collisions, during the Early Palaeozoic between Tarim and Central Tianshan blocks, and during the Late Palaeozoic between Central Tianshan and North Tianshan (Windley et al. 1990; Allen et al. 1993; Gao et al. 1998; Chen et al. 1999; Carroll et al. 2001; Zhou et al. 2001), but there is no agreement about the end of convergence. Generally, the convergent orogeny is considered to be terminated before the Early Permian (Wang et al. 1994; Liu et al. 1996; Xiao et al. 2004, 2006; Gao and Klemd 2003; Klemd et al. 2005; Gao et al. 2006; Li et al. 2006a; Charvet et al. 
2007), and this phase of amalgamation was followed by regional-scale Late Palaeozoic (Permian) wrench faulting (Allen et al. 1995; Allen and Vincent 1997; Laurent-Charvet et al. $2002,2003)$. Some authors argued that continent amalgamation was accomplished in the preCarboniferous and that a post-collisional continental rifting occurred during the Carboniferous to Permian (Che et al. 1996; Xia et al. 2004b). Others suggest that the collision in southwestern Tianshan occurred as late as Late Permian-Triassic (Li et al. 2002, 2005; Zhang et al. 2007).

The magmatic affinities and emplacement ages provide keys for understanding the geodynamic evolution of the orogen, but in Chinese Tianshan, the coexistence of Carboniferous to Permian calc-alkaline and alkaline magmatic rocks has inferred contrasting interpretations. It has been widely accepted that the Carboniferous magmatism is subductionrelated and/or syncollisional, and the Permian one is post-collisional. However, Carboniferous-Permian volcanic rocks were also interpreted as a result of continental rifting (Che et al. 1996; Xia et al. 2004b); or parts of a Large Igneous Province (Xia et al. 2004a, 2006 ) although these views are not supported by compelling tectonic or stratigraphic evidences.

Recent studies suggest that the genetic links may exist between Permian wrench faulting and post-collision magmatism, and therefore could be a clue for understanding the evolution of the Chinese Tianshan during this period. This article presents our field observations, new zircon U-Pb LA-ICPMS dating and geochemical data from Permian igneous rocks of the western Chinese Tianshan. Combining with previous data, we discuss the petrogenesis of Permian igneous rocks and suggest that most petrologic features were controlled by the location of wrench faults that allowed local asthenosphere uplift and transition from calcalkaline to alkaline magmas to occur.

\section{Geologic setting}

The Late Palaeozoic evolution of the Chinese Tianshan is characterized by polyphase deformation and transition from continental active margin to intraplate tectonics. The preCarboniferous subduction finally induced a continental collision between the Yili Block and Tarim in Early Carboniferous ( $\sim 345 \mathrm{Ma})$ along the HP/LT metamorphic zone in SW of the Tianshan Belt (Fig. 1; Allen et al. 1993; Gao et al. 1998; Gao and Klemd 2003; Wang et al. 2007c). During the Carboniferous, massive limestone, pelitic limestone and sandstone were deposited (XBGMR 1993). Meanwhile, in the NW part, extensive volcanic rocks (mainly andesite and rhyolite) erupted indicating a long-term magmatic activity (Figs. 1, 2). Between the latest Carboniferous and Early-Middle(?) Permian, in the North Tianshan (Fig. 1), the formation of an ophiolitic mélange including blocks of Late Carboniferous oceanic crustal rocks and turbidites suggests that the amalgamation of continental blocks came to the end (Windley et al. 1990, 2007; Allen et al. 1993; Wang et al. 2006a).

During the Permian, large-scale dextral ductile shearing occurred along the North Tianshan Fault (Allen and Vincent 1997; or Dzhungarian Fault by Zhang et al. 1993) and Main Tianshan Shear Zone (Laurent-Charvet et al. 2003), and along the Qingbulak-Nalati Fault (Windley et al. 1990) and Sangshuyuanzi Fault (Yin and Nie 1996) (faults 1, 2, 3 and 4 in Fig. 1, respectively). They are developed in a LP-HT thermal regime as testified by the widespread development of synkinematic andalusite (Wang et al. 2006a). The age of ductile deformation is constrained at ca. $290-245 \mathrm{Ma} \mathrm{by}{ }^{40} \mathrm{Ar} /{ }^{39} \mathrm{Ar}$ dating of synkinematic feldspar (Zhou et al. 2001) and biotite (Yin and Nie 1996; Laurent-Charvet et al. 2002, 2003; de Jong et al. 2008, this volume). In Central Asia as a whole, a Permian transcurrent regime followed 
the earlier N-S-directed convergence (Bazhenov et al. 1999, 2003; Allen et al. 2006; Van der Voo et al. 2006; Wang et al. 2007b). During this period, a major paleogeographic change occurred in the Chinese Tianshan, and terrestrial sediments associated with sub aerial volcanic rocks deposited unconformably or disconformably over Carboniferous sedimentary and volcanic rocks. In contrast, in restricted areas such as the south of Bogda Mountain (Fig. 1 ), deep water sediments accumulated in elongated troughs where they overlie collapse breccia (olistoliths) and pillow basalt (Shu et al. 2005).

\section{A synthesis of previous data}

Carboniferous and Permian igneous rocks are widespread in the Chinese Tianshan Belt (Fig. 1). In order to get a unified understanding on the geochemistry and chronology of these magmatic rocks, the following paragraphs summarise the previous data, except for undated or poorly time-constrained rocks that will not be considered. According to their geochemical features, three types of magmatic rocks are defined, namely calc-alkaline (CA), alkaline (A) and transitional series (TR, calc-alkaline rocks with prominently high REE contents) (see Table 1).

\section{Carboniferous magmatism}

Carboniferous volcanic rocks consist of mafic, intermediate and felsic rocks (XBGMR 1993) that are exposed in the Borohoro, Awulale, Nalati and Wusun mountains (Figs. 1, 2). The Lower Carboniferous Dahalajunshan Formation $\left(C_{1} d\right)$ is well known for its extensive distribution and remarkable thickness. It is mainly composed of andesite, rhyolite, felsite, tuff breccia and minor basalt, associated with limestone and sandstone. The volcanic rocks show significant depletion in $\mathrm{Nb}$ and $\mathrm{Ta}$, moderate depletion of $\mathrm{Hf}$ and $\mathrm{Zr}$, and prominent enrichment in $\mathrm{Rb}$ and Th (Li et al. 1998; Ma and Wang 2000; Yang et al. 2003; Zhang and Li 2006; A et al. 2006; Guo and Zhu 2006; Li et al. 2006b; Shao et al. 2006). The intermediate to acidic volcanic rocks of the Lower Carboniferous Akeshake Fm. $\left(\mathrm{C}_{1} \mathrm{a}\right)$ and Upper Carboniferous Tuergong Fm. $\left(\mathrm{C}_{2} \mathrm{t}\right)$ in the Nalati range have similar geochemical compositions (Wang et al. $2007 a)$, they show positive $\varepsilon_{\mathrm{Nd}}(t)$ values $(+0.32$ to +4.90$)$, and variable ${ }^{87} \mathrm{Sr} /{ }^{86} \mathrm{Sr}$ (i) ratios (0.7015-0.7068) (Zhu et al. 2005, 2006a; Guo and Zhu 2006; Qian et al. 2006). Recent SHRIMP zircon U-Pb dating provided consistent Carboniferous ages (363$313 \mathrm{Ma}$, Zhu et al. 2005, 2006b; Zhai et al. 2006). These volcanic rocks are defined as CA series in Table 1.

Carboniferous adakites were recognized in Alataw, Borohoro and Baluntai areas (Fig. 1) and show high $\mathrm{Sr}$, Eu compositions, $\varepsilon_{\mathrm{Nd}}(t)$ values $(+1.5$ to +10.0$)$, and low $\mathrm{Y}, \mathrm{Yb}$ contents and ${ }^{37} \mathrm{Sr} /{ }^{86} \mathrm{Sr}(\mathrm{i})$ ratios $(<0.7070)$ (Wang et al. 2003, 2006b; Zhao et al. 2003b, 2006). The volcanic rocks of the Upper Carboniferous Yishijilike Fm. $\left(\mathrm{C}_{2} \mathrm{y}\right)$ in the Awulale range (Figs. 1, 2) display enrichment in incompatible elements and a moderate $\mathrm{Ta}$ and $\mathrm{Nb}$ negative anomaly (Liu et al. 2006). The Lower Carboniferous andesite and rhyolite of Borohoro and Wusun mountains show high Ti/Y $(>500), \mathrm{Ce} / \mathrm{Y}(>3)$ ratios, and relatively low total Fe (5.8-7.8 ppm) (Che et al. 1996; Xia et al. 2004b); the Carboniferous basalt, andesite and rhyolite in Baluntai and Bogda areas have lower Ti/Y $(<500), \mathrm{Ce} / \mathrm{Y}(<3)$, high Total Fe $(6.4-11 \mathrm{ppm})(\mathrm{Xia}$ et al. $2004 b)$. These "rift-related" volcanic rocks are characterized with positive $\varepsilon_{\mathrm{Nd}}(t)$ values $(+4.1$ to +9.7$)$ and consistent ${ }^{87} \mathrm{Sr} /{ }^{86} \mathrm{Sr}(\mathrm{i})$ ratios $(0.7034-0.7059)$ suggesting origin from a mantle source and weak crustal contamination (Xia et al. 2004b). These rocks are not directly dated, and therefore are not listed in Table1. 
Carboniferous plutonic rocks in Wusun, Nalati and west of Borohoro mountains (Fig. 1) were formed during 352-308 Ma interval (zircon U-Pb TIMS by Xu et al. 2006 and LA-ICP-MS by Wang et al. 2006a). Geochemistry indicates that they are mainly I-type granites associated with minor S-type granites (Wang et al. 1993; Li et al. 1995), they display enrichment in Rb, $\mathrm{Th}$ and depletion in $\mathrm{Nb}, \mathrm{Ta}, \mathrm{Zr}$ and $\mathrm{Hf}$ (Xu et al. 2006). In the east of Alataw area, I-type granodiorite and $\mathrm{K}$-granite at ca. $307-290 \mathrm{Ma}\left({ }^{40} \mathrm{Ar} /{ }^{39} \mathrm{Ar}\right)$ display a weak LREE enrichment and strong enrichment in $\mathrm{K}, \mathrm{Rb}$; the $\varepsilon_{\mathrm{Nd}}(t)$ values $(0$ to +7$)$, and ${ }^{87} \mathrm{Sr} /{ }^{86} \mathrm{Sr}(\mathrm{i})$ ratios $(0.7020$ 0.7110) (Chen et al. 1994, 2000; Zhou et al. 1994, 1995, 1996) are characteristic of the calcalkaline series and therefore they are correlated to type CA (Table 1).

\section{Permian magmatism}

The Permian of the western Chinese Tianshan is characterized by plant-bearing conglomeratic red-beds that unconformably overlie older strata (XBGMR 1993). The relatively small-sized granitoids that are generally referred to as "Late Hercynian plutons" on 1/200,000 maps (e.g. XBGMR 1973) are distributed widely in the study area (Fig. 1). On the basis of recent U-Pb zircon dating, they predominantly belong to Permian with only a few Late Carboniferous rocks. In the southern Tianshan, diorite and porphyritic granite were formed during ca. 298 $284 \mathrm{Ma}$ (U-Pb dating on zircon), they are rich in $\mathrm{K}, \mathrm{Rb}$, Th, and depleted in $\mathrm{Ta}, \mathrm{Nb}$ and $\mathrm{Zr}$; alkali feldspar granite was emplaced during 265-260 Ma, and shows enrichment in $\mathrm{Nb}, \mathrm{Y}$, LREE, and lower Ti, Sr and Ba contents (Jiang et al. 1999). In Alataw area, the S-type Kgranite and monzonite were formed during $298-271 \mathrm{Ma}\left({ }^{40} \mathrm{Ar} /{ }^{39} \mathrm{Ar}\right.$ and zircon U-Pb LaICPMS), they have flat REE distribution patterns, depletion in $\mathrm{Ba}, \mathrm{Nb}, \mathrm{Sr}$ and $\mathrm{Ti}$, enrichment in $\mathrm{Rb}, \mathrm{K}, \mathrm{U}$ and $\mathrm{Th}$, and positive $\varepsilon_{\mathrm{Nd}}(t)$ values $(+2.1$ to +5.2$)$ (Chen et al. 1994, 2000; Zhou et al. 1994, 1995, 1996; Liu et al. 2005).

Lower-Middle Permian volcanic rocks are locally distributed in Awulale, Nalati and Alataw areas (XBGMR 1993; Figs. 1, 2). The volcanic and hypabyssal rocks of Awulale and Nalati areas were dated at 296-260 Ma $\left({ }^{40} \mathrm{Ar} /{ }^{39} \mathrm{Ar}\right.$; Zhao et al. 2003b). The Wulang Fm. $\left(\mathrm{P}_{1} \mathrm{w}\right)$ that develops in the Awulale and Altaw areas is composed of tuffaceous breccia, crystal-bearing tuff, amygdaloidal basalt, porphyritic augite-andesite, rhyolitic porphyrite and dacitic porphyrite (Fig. 2). In Awulale range, Middle Permian Hamist Fm. $\left(\mathrm{P}_{2} \mathrm{~h}\right)$ consists of basalt, rhyolite, sodic dacite, albitophyre and tuffaceous mudstone that bears fish fossils (XBGMR 1993) (Fig. 2). The albitophyre $\left(260 \pm 5 \mathrm{Ma},{ }^{40} \mathrm{Ar} /{ }^{39} \mathrm{Ar}\right.$ plateau age) show high $\mathrm{Sr}$, low $\mathrm{Yb}$ and $\mathrm{Y}$ contents, less variable $\mathrm{Nd}$ isotopic ratios $\left({ }^{143} \mathrm{Nd} /{ }^{144} \mathrm{Nd}(\mathrm{i})=0.5124-0.5125 ; \varepsilon \mathrm{Nd}(t)=+1.57\right.$ to +3.26$)$, and low $\mathrm{Sr}$ isotopic ratios $\left({ }^{87} \mathrm{Sr} /{ }^{86} \mathrm{Sr}(\mathrm{i})=0.7051-0.7054\right)$ (Xiong et al. 2001). To the Northeast of Nalati range, volcanic rocks develop within terrestrial red beds of Aikendaban Fm. ( $\left.\mathrm{P}_{2} \mathrm{a}\right)$ (Fig. 2), felsite and trachyte yield whole rock K-Ar age of ca. 270-260 Ma, associated trachytic basalt show slight LREE enrichment depletion in $\mathrm{Zr}, \mathrm{Hf}, \mathrm{Nb}$, Ta and $\mathrm{Ba}$; while trachyte andesite is significantly rich in LREE and depleted in $\mathrm{Sr}$ (Chen et al. 2004a, b). To the south of Bogda range, where collapse breccia and deep-water sediments overlie alkaline pillow basalt, a mafic feeding dyke yields Early Permian zircons ( $289 \pm 5 \mathrm{Ma}, \mathrm{U}-\mathrm{Pb})$ (Shu et al. 2005).

The above-mentioned magmatic rocks are diversely correlated to CA, A and TR types (Table 1). Thus, they could neither be simply related to an extensional intraplate setting, nor to a subduction regime. It appears that the complex geochemical features present in the study area can not unambiguously constrain the geodynamic setting at a given period. The Carboniferous magmatic rocks are mostly of CA type, whereas diverse suites (CA, A and TR) coexist during the Permian. Therefore, it is necessary to take into account every field and 
structural features before proposing an evolutionary model. In order to get more constraints on the chronology and petrogenesis of the Permian magmatism, several key sections across the main wrench faults were investigated in the following sections.

\section{The Borohoro plutons}

The Borohoro plutons develop to the south of the North Tianshan Fault (NTF) in a poorly accessible area. They show a spindle shape extending parallel to the NTF (Figs. $\underline{1}, \underline{3}$ ). They were previously correlated with the Carboniferous on 1:1,500,000 and 1:200,000 geological maps (XBGMR 1973, 1975, 1993), but remained undated and their geochemical compositions were unknown.

\section{Petrology}

The Borohoro plutons are mainly composed of greyish-white biotite granite and pink Kgranite; both are characterized by coarse grain texture, and typically consist of plagioclase, $\mathrm{K}$ feldspar, quartz, biotite and hornblende; Biotite often occurs as euhedral grains and rarely as amphibole pseudomorphs. In K-granite, pyroxene relics are preserved in poikilitic hornblende. Accessory minerals include apatite, zircon and ilmenite.

\section{Internal structure}

A deformation fabric can be recognized in most rocks of the Borohoro plutons, it comprises shallow linear and steep planar textures. The lineation is defined by aligned biotite, hornblende, and feldspar grains and elongated quartz aggregates, the planar fabric is marked by ribbons of mafic minerals (Fig. 4a). Micro-texture does not show significant internal deformation in euhedral grains of plagioclase, biotite, hornblende and interstitial ovoid quartz, although locally quartz domains display minor sutured boundaries and weak ondulose extinction, and occasional fracturing and disaggregation of the grain corners (Fig. 4b). These are typical high-temperature fabrics developed in condition of pre-critical melt percentage (e.g. Tribe and D'Lemos 1996) suggesting a still magmatic state deformation. Although no systematic investigation has been undertaken, the planar fabric strikes $\mathrm{N} 120^{\circ}-\mathrm{N} 130^{\circ}$, slightly oblique to the strike of the NTF, but parallel to the intrusion margin.

\section{Relationships with country rocks and the NTF}

The Silurian-Devonian (?) and Early Carboniferous host rocks of the Borohoro plutons (Fig. 3) display an unusual kind of contact metamorphism. Spotted slate often develops within the contact zones while hornfels is rare. The host rock is characterized by steeply dipping foliation that bears a shallow dipping stretching lineation with andalusite porphyroblasts. This foliation represents the effect of syntectonic thermal metamorphism due to synkinematic granite intrusion associated with a ductile shear zone (Wang et al. 2006a). Along the northern margin of the plutons, metre- to decimetre-scale sheets of pink K-granite dykes intrude Carboniferous turbidite. Although some are randomly oriented, most of granitic dykes have an east-west trend, sub-parallel to the NTF, suggesting a structural control on magma emplacement as well.

\section{Kekesu and Gangou sections}

In order to make a comparison, two sections were also investigated in the Qingbulak-Nalati and Sangshuyuanzi shear zones, which are briefly described below. In the Kekesu section (Fig. 5), massive pink granites are composed of K-feldspar, plagioclase, quartz and minor mafic minerals that are often chloritized and/or epidotized, they intrude cataclastic or 
mylonitized gabbro of Devonian to Carboniferous age and probable Proterozoic orthogneiss. Locally, K-granite dykes are boudinaged or folded, showing axial plane parallel to the SWNE trending gabbro foliation (Fig. 4c, d). Within this shear zone, Carboniferous granite (313 $\pm 4 \mathrm{Ma}, \mathrm{U}-\mathrm{Pb}$ age on zircon) underwent ductile deformation and yield Middle Permian biotite $\left(263.4 \pm 0.6 \mathrm{Ma},{ }^{40} \mathrm{Ar} /{ }^{39} \mathrm{Ar}\right.$ plateau age) related to Ar loss during mylonitisation (Wang et al. 2007c). The boundaries of the K-granite are generally parallel to the Qingbulak-Nalati fault zone (Fig. 5), indicating a close relationship between the emplacement of granite and the shear zone.

In Gangou area, the Sangshuyuanzi Fault extends parallel to the SE-NW Main Tianshan Shear Zone (MTSZ) which is connected westwards with the NTF (Figs. 1, 6). K-granite and synchronous dykes showing a SE-NW elongated shape intrude Proterozoic orthogneiss and Silurian-Carboniferous strata. Both K-granite and its country rock display a well developed mylonitic foliation that strikes $\mathrm{N} 130^{\circ} \mathrm{E}$ (Fig. 4e), and typically bears a low dip stretching lineation $\left(15^{\circ}-20^{\circ} \mathrm{SE}\right)$. Sigmoid K-feldspar and asymmetrical biotite pressure shadow reveal a dextral ductile deformation (Allen et al. 1995; Allen and Vincent 1997; Laurent-Charvet et al. 2002). Although the granite underwent significant mylonitisation, a coarse to medium grain texture can be recognized, K-feldspar, quartz, plagioclase, minor biotite and sometimes amphibole are the main minerals.

\section{New geochronological and geochemical data}

Two biotite granite and two K-granite samples were collected from the Borohoro plutons, one K-granite and one biotite K-granite samples were collected from the Kekesu and the Gangou sections, respectively. Sampling locations are shown in Figs. 3, 5, 6 and Table 2.

\section{Analytical techniques}

The selected samples were crushed and milled into rock powder, zircon crystals are enriched using heavy liquids and magnetic separator, and finally selected by handpicking under binocular microscope. Euhedral and colorless zircon grains were selected for laser ablation $\mathrm{U}-\mathrm{Pb}$ dating that was carried out at the University of Tasmania, Australia, using a Hewlett Packard HP 4500 quadrupole Inductively Coupled Plasma Mass Spectrometer (ICP-MS) coupled with a $213 \mathrm{~nm}$ NewWave Merchantek UP213 Nd-YAG Laser. Preserved rock powder was used for whole rock geochemical analyses by ICP-AES for major elements and by ICPMS for incompatible and rare earth elements at Centre de Recherches Pétrographiques et Géochimiques (CRPG-CNRS, Nancy, France). The limit of determination is less than $0.07 \%$ for major elements, and less than $0.5 \mathrm{ppm}$ for most of trace elements, and up to 1.5 $6 \mathrm{ppm}$ for $\mathrm{Ba}, \mathrm{Cr}, \mathrm{Sr}, \mathrm{Zn}$ and $\mathrm{Zr}$. Analytical uncertainties are given as $2 \%$ for major elements, and 5 or $10 \%$ for trace element concentrations around $20 \mathrm{ppm}$, and the precision for REE is estimated at 5 or $10 \%$ depending on the chondrite-normalised concentrations are $>10 \mathrm{ppm}$ or lower, respectively.

\section{LA-ICPMS dating}

Six granitoids samples were dated, and twelve zircon single grains were analysed for each sample. The results are shown in Table 2 and plotted on reversed Concordia diagrams (Fig. 7). Although different in $U$ and Th absolute compositions, all zircons show consistently accordant $\mathrm{Th} / \mathrm{U}$ ratios of $>0.2$, indicating a magmatic origin (Vavra et al. 1996). Four granitoids from Borohoro Mountain were dated. The formation time of the granodiorite sample B101 can be constrained by nine zircons yielding a concordant age of $294 \pm 7 \mathrm{Ma}$ (Fig. 7a), while the rest three zircons provide older ages of 312-589 Ma that probably represent inherited zircon derived from Palaeozoic country rocks. Zircons of granodiorite 
sample B94 can be divided into two groups, wherein the uranium contents of high U zircons are ten times more than those of low $\mathrm{U}$ ones (Table 2). The first low $\mathrm{U}$ zircon was rejected due to lots of common $\mathrm{Pb}$, five low $\mathrm{U}$ zircons and one high $\mathrm{U}$ zircon yield consistent apparent ages defining a concordant age at $272.8 \pm 6 \mathrm{Ma}$, and the last low U zircon together with the other four high $U$ zircons yield a concordant age at $293 \pm 0.5 \mathrm{Ma}$ (Fig. 7b); The latter one is consistent with the age of the sample B101 at the uncertainty level, but the former one is significantly younger, indicating that the granodorite was emplaced during two distinct episodes. All zircons together give an average age at 285.3 $\pm 7.3 \mathrm{Ma}$.

For the K-granite sample $\mathrm{B} 95$, the first zircon display high common $\mathrm{Pb}$ content throughout the analysis inducing young age and large analytical uncertainty $(225 \pm 10 \mathrm{Ma})$, the second one also yield a rather younger age of $247 \pm 4$ Ma but shows no analytical anomaly, this is probably due to statistical outlier. The last zircon yielding an age of $340 \pm 3 \mathrm{Ma}$ is likely an inherited one mixed with older core. The rest nine zircons provide accordant ages ranging from 257-277 Ma that are used to calculate a concordant age at $266 \pm 6 \mathrm{Ma}$, indicative of the formation time of the K-granite (Fig. 7c). On the Concordia diagram (Fig. 7d) of the Kgranite B102, except one point that was rejected due to discordant apparent age, the other eleven points were used in the calculation of concordant age at $280 \pm 5 \mathrm{Ma}$.

Seven zircons from the Kekesu K-granite KKS5 yield concordant apparent ages that are used to calculate a weighted average $\mathrm{U}-\mathrm{Pb}$ age at $277 \pm 3 \mathrm{Ma}$. Older ages of 312-375 Ma are also obtained from two zircons that were probably derived from foliated/mylonitized country rocks. The other three points are discordant because of either $\mathrm{Pb}$ loss in high $\mathrm{U}$ zircon (the first point), or high proportion of common $\mathrm{Pb}$ (the last one) (Fig. 7e) and consequently provide geologically meaningless ages.

From the Gangou K-granite KMX13, eight points concordantly define a U-Pb age at $252 \pm 4 \mathrm{Ma}$ (Fig. 7f), and can be interpreted as the intrusion time of the K-granite. The last four zircons yield significantly older ages ranging from 312 to $357 \mathrm{Ma}$ (Table 2; Fig. 7f), which may reflect the incorporation of zircon xenocrysts derived from Carboniferous country rocks. The occurrence of Devonian-Carboniferous strata and granitic rocks around the Kgranite (Fig. 6; XBGMR 1993; Xu et al. 2006) confirms this interpretation.

\section{Geochemical composition}

Only four granitic rocks from Borohoro Range were analysed for whole rock geochemistry. Table 3 comprises the already published geochemical data and our new results. Borohoro granites are significantly rich in alkali (7-9.7 wt $\%$ ) with relatively high content of $\mathrm{K}_{2} \mathrm{O}$ with respect to $\mathrm{Na}_{2} \mathrm{O}$. Relative low aluminum contents (13.8-14.1 wt\%; Aluminum Saturation Index $\approx 1$ ) indicate that they belong to metaluminous or slightly aluminous I-type granitoid series (Fig. 8).

The samples B101 and B102 are characterized by enrichment in $\mathrm{Rb}$, Th and $\mathrm{K}$ compared to $\mathrm{REE}$, and low contents of $\mathrm{Nb}$ and $\mathrm{Ta}$ (Table 3), indicative of calc-alkaline series. However, the samples B94 and B95 show lower Ba (125-134 ppm) and $\mathrm{Sr}(20-40 \mathrm{ppm})$, characteristic of transitional type as defined above. A similar feature, e.g. co-existence of both calc-alkaline and transitional series, occurs for Alataw and southern Tianshan granitoids (Jiang et al. 1999; Liu et al. 2005). This feature can be observed on the expanded REE and trace elements spider diagram normalized to the primitive mantle (Sun and McDonough 1989) (Fig. 9a), in which, all the granitic rocks of Borohoro, Alataw and southern Tianshan as well as Nalati volcanitic 
rocks exhibit a regular decrease with increasing compatibility for HFS elements. In addition, depletions of $\mathrm{Nb}, \mathrm{Ta}, \mathrm{Y}$ and $\mathrm{Yb}$ can be observed for all these magmatic rocks. Otherwise, the samples B94 and B95 exceptionally show enrichments of Ce, $\mathrm{Zr}$ and $\mathrm{Hf}$.

The samples B101 and B102 display total REE content of 90-188 ppm, slight LREE enrichment $\left(\mathrm{La}_{\mathrm{N}} / \mathrm{Yb}_{\mathrm{N}}=5.7-7.2\right)$, weak negative Eu anomaly $(\delta \mathrm{Eu}=0.6-0.88)$. They have low $\mathrm{Ce} / \mathrm{Pb}(1.7-3.7)$ and $\mathrm{Nb} / \mathrm{La}(\approx 0.4)$ ratios, and $\mathrm{Th} / \mathrm{La}$ ratio of $0.4-0.7$ (Table 3). These features, consistent with calc-alkaline granites, are similar to those of Alataw granitoids, southern Tianshan two-mica granite and potassium granite (Table 3). In contrast, the samples B94 and B95 have higher REE contents (231-236 ppm), higher $\mathrm{La}_{\mathrm{N}} / \mathrm{Yb}_{\mathrm{N}}(16.8-20.9)$ and $\mathrm{Ce} / \mathrm{Pb}(7.7-6.9)$ ratios, and lower $\mathrm{Nb} / \mathrm{La}(\approx 0.16)$ and $\mathrm{Th} / \mathrm{La}(\approx 0.15)$ ratios (Table 3$)$. These features are those of alkaline or transitional granites, and are comparable to the characteristic of the trachytic andesite from Nalati and granodiorite from southern Tianshan (Table 3). On the Chondrite-normalized REE patterns (Fig. 9b; Pearce 1982), samples B101 and B102 of Borohoro plutons, and Alataw granitoids show lesser REE fractionation by comparison with the samples B94 and B95 as well as the volcanic rocks of the Nalati and Bogda areas.

\section{Discussion}

\section{Persistence and evolution of magmatism through Carboniferous to Permian}

On the basis of our study of the Borohoro plutons, the high-K calc-alkaline granites formed during 294-280 Ma, whereas the transitional plutonism occurred between 285 and $266 \mathrm{Ma}$, and continued until $250 \mathrm{Ma}$ in other places. Combining the previous results synthesized above, the magmatic activity in western Chinese Tianshan was a permanent process that started as early as the beginning of Carboniferous and lasted up to the end of Permian. Geochemical compositions suggest that the Carboniferous magmatic rocks are mainly calcalkaline although a few transitional series may occasionally appear (Table 1 ); in contrast, the Permian magmatic rocks are characterised by the coexistence of calc-alkaline, alkaline and transitional series, indicating a transition of magma chemistry from calc-alkaline to alkaline.

\section{Petrogenesis of Carboniferous-Permian magmatic rocks and geodynamic implications}

Some authors favor a continental rift (Che et al. 1996; Xia et al. 2004b) or an intra-plate environment (Liu et al. 2006) for the Carboniferous volcanic rocks, and a post-collision setting for the Carboniferous granites (Xu et al. 2006). Nevertheless, their geochemical and isotopic features indicate that subduction play a prominent role, such as suggested by the occurrence of adakite, high-Mg andesite, and Nb-poor andesitic basalt (Wang et al. 2003, 2006b; Zhao et al. 2003b, 2006). Moreover, stratigraphic features of Carboniferous volcanic rocks and the shallow water sedimentary association (Fig. 2) suggest a rather long period of eruption on a continental margin. Elsewhere in Central Asia, Carboniferous subductionrelated and/or syncollisional igneous rocks with calc-alkaline affinities are reported in the South Tianshan belt of Kyrgyzstan (Hamrabaev and Simon 1984; cited by Solomovich and Trifonov 2002) and around the Tu-Ha basin of the Chinese eastern Tianshan (Li et al. 2001, $2006 a, b$; Sun et al. 2006). Therefore, Carboniferous magmatic rocks have most probably been generated in an active margin setting.

Usually, the Permian high-K calc-alkaline and alkaline igneous rocks were considered to be post-collisional, e.g. in the South Tianshan of Kyrgyzstan (Solomovich and Trifonov 2002; Solomovich 2007). Particularly, the Permian high-K calc-alkaline and transitional granites of the Borohoro plutons also have subduction components according to the low $\mathrm{Ce} / \mathrm{Pb}$ and 
$\mathrm{Nb} /$ La ratios (Table 3) indicating the influence of subduction-derived fluids on the subcontinental mantle wedge (Hofmann et al. 1986); moreover, the high $\mathrm{Th} / \mathrm{La}$ ratios suggest influence of subducted sediments (Plank 2005). It is also the cases for the volcanic rocks of Aikedaban Fm., for Alataw granitoids except the granitic dyke, and for the granodiorite and phorphyritic granite of the southern Tianshan. However, it seems not necessary to conclude that these magmatic rocks were produced in an active margin since subduction components may be inherited from the subcontinental mantle lithosphere in a post-collisional setting. Thus, the high-K calc-alkaline and transitional granites of Borohoro plutons show a compositional signature similar to either mature continental arcs or post-collisional settings, but limited geochemical arguments are not conclusive to discriminate between an active margin and a post-collisional environment for these magmatic rocks.

The Permian magmatic rocks are also considered to form during a continental rifting. However, In Awulale area, Permian volcanic and intrusive rocks as well as red molasses deposits are well developed, our structural investigation reveals that neither normal faults nor strike-slip faults predominate. Otherwise, considering the extensive distribution of Permian and Carboniferous magmatic rocks in northern Chinese Tianshan, the hypothesis of Large Igneous Province was proposed by Xia et al. $(2004 a, 2006)$ and correlated with a mantle superplume. Using geochemical and isotopic data, these authors suggest an asthenospheric magma source similar to that of Hawaii and Iceland. Nevertheless, the diversity of magma sources, the predominance of Carboniferous calc-alkaline magmas and the presence of ophiolitic mélanges do not fit this interpretation. In addition, the extremely long duration of magmatic activity ( $>110 \mathrm{Ma}$ from 360 to $250 \mathrm{Ma}$ ) is rather unusual for mantle plumes over the world that generally result in continental break-up within less than 20-30 Ma. Moreover, no other criteria for identifying ancient mantle plume, such as crustal uplift prior to volcanism, radial dyke swarms, volcanic chain or thick plateau basalt (e.g. Campbell 2001), are documented in Tianshan, or even in Central Asia. Thus, on the basis of field observation, lithological features, geochemical and geochronological data, another interpretation may be proposed for the generation of Permian magmatism in Chinese Tianshan.

The Late Carboniferous to Permian magmatism of the northwestern Chinese Tianshan displays a compositional variation from highly fractionated calc-alkaline to alkaline, indicating the contribution of multiple magma sources in a transitional tectonic regime (Black and Liégeois 1993; Liégeois et al. 1998; Bonin 2004). This feature often occurs in large-scale shear zones in a post-collisional setting where the previously metasomatised mantle wedge, underplated mafic material, and uplifted asthenosphere, are possible sources for magmas in a high regional heat flow (Cluzel et al. 1991, 1994; D'lemos et al. 1992; Hutton and Reavy 1992; Tommasi et al. 1994; Saint Blanquat et al. 1998; Steenken et al. 2000; Weinberg et al. 2004; Rosenberg 2004; Njanko et al. 2006; Oyhantçabal et al. 2007). According to available geological maps and our field observations, the Borohoro plutons and granites of Kekesu and Gangou areas were emplaced within or at the margins of transcurrent shear zones, some have an "en cornue" shape (Figs. 1, 3, 5, 6) developing high-temperature fabrics, and therefore may be considered as synkinematic. The North Tianshan Fault, the Qingbulak-Nalati Fault and the Sangshuyuanzi Fault are major ductile dextral strike-slip faults (Allen et al. 1995; Allen and Vincent 1997; Wang et al. 2006a) that crosscut the lithosphere according to seismic data (Zhao et al. 2003a; Wang et al. 2004). The cooling age of these shear zones is constrained between 285 and $245 \mathrm{Ma}$ on the basis of ${ }^{40} \mathrm{Ar} /{ }^{39} \mathrm{Ar}$ dating of biotite from mylonites (Yin and Nie 1996; Zhou et al. 2001; Laurent-Charvet et al. 2003; de Jong et al. 2008, this volume), confirming a close temporal relationship between pluton intrusion and ductile wrench tectonics. Therefore, Permian large-scale wrench faulting likely induced and controlled the 
emplacement of synchronous magma with diverse sources. This interpretation is supported by numerical modeling by Weinberg et al. (2004), which reveals that some fragile, dilatational spaces with low mean pressure can be produced during crustal-scale transcurrent shearing because of the changes in the rheological properties of rocks, favouring magmas ascent and pluton emplacement. The prominent post-collisional fluid activity and gold mineralization associated with transcurrent shear zones in Chinese Tianshan and Central Asia as a whole (Mao et al. 2004; Yakubchuk 2004; Han et al. 2006; Xiao et al. 2006) are also consistent with syn-kinematic magmatism.

Post-collisional evolution from calc-alkaline to alkaline magmatism usually occurs during a gradual transition between syn-orogenic convergence and post-orogenic intra-continental extension as observed in western Mediterranean area (Coulon et al. 2002; Duggen et al. 2005; Lustrino et al. 2007), Pan-African Central Cameroon and Uruguay (Njanko et al. 2006; Oyhantçabal et al. 2007). This transition may be brought on after continental collision or subduction extinction. Taking into account all the available geological data (e.g. Windley et al. 1990; Allen et al. 1993; Gao et al. 1998; Xiao et al. 2004; Charvet et al. 2007), kinematic observations (Laurent-Charvet et al. 2002, 2003; Wang et al. 2006a) and paleomagnetic evidences (Van der Voo et al. 2006; Wang et al. 2007b), the Carboniferous convergence was followed by the Permian large-scale post-orogenic dextral transcurrent tectonics. We propose that the transcurrent tectonics at least partly induced the synkinematic magmatism and provoked the Early-Middle Permian transition from high-K calc-alkaline to alkaline magmatism (Fig. 10). The occurrence of Middle to Late Permian thick red molasse (XBGMR 1993; Cui et al. 1996; Carroll et al. 1995) is a rather strong evidence for post-orogenic setting; in contrast, the localised occurrence of Permian deep seated sediments (turbidites) closely associated with alkaline mafic rocks (e.g. southern Bogda area) infers that Permian strike-slip tectonics generated narrow zones of thinned lithosphere (pull-apart basins) in which volcanic rocks were generated by the melting of uplifted asthenosphere. Such lithospheric thinning could be correlated to an east-west extension as proposed by Wartes et al. (2002). It is worth noting that the thinned area partly involved the Carboniferous mantle wedge. In this case, previously matasomatised mantle rocks coexist with uplifted juvenile asthenosphere, and source or magma mixing may easily occur. Within the Permian shear zones, source mixing is likely to be lesser than on the boundaries and "real" alkaline magmas may be generated; in contrast, away from the Permian shear zones, calc-alkaline magmatism (the so-called postcollisional plutons) may persist in the absence of juvenile asthenospheric mantle (Fig. 10b). However, this proposition should be convinced by further studies.

\section{Conclusions}

Geochemical and geochronological data indicate that Borohoro high-K calc-alklaine granites formed between 294 and $280 \mathrm{Ma}$, while transitional and alkaline granites of Borohoro plutons, Kekesu K-granite and Gangou K-granite were produced during 285-252 Ma. Considering the present study and previous data, it appears that igneous activity during Carboniferous to Permian in western Chinese Tianshan was a permanent process showing an evolution from calc-alkaline to alkaline, the transition occurred during the Early-Middle Permian.

Early to Middle Permian magmatic association of high-K calc-alkaline, transitional and alkaline granites suggests a post-collisional setting. Previously proposed continental rift and supra mantle plume are unlikely for the genesis of these magmatic rocks because the lack of field evidence other than geochemistry. Conversely, distinctive spatial and temporal 
relationships between pluton emplacement and dextral strike-slip faulting are observed. Although additional detailed studies are needed, it may be proposed that the Early-Middle Permian magmatism, at least in part, occurred during regional-scale transcurrent tectonics, as a transitional event from Carboniferous convergence to Middle-Late Permian anorogenic environment.

Acknowledgments The authors are grateful to Dr. W.J. Xiao for inviting this contribution. We acknowledge the accurate work by Dr. M.B. Allen and another anonymous reviewer, their comments and suggestions have been extremely useful for improving our manuscript. The research work was financially supported by the National Basic Research Program of China (973 Program) (Nos. 2007CB411301 and 2001CB409804). French Embassy in Beijing, the French-Chinese Advanced Research Program (PRA T05-02) and Taiwanese CREATE project (Institute of Earth Sciences, Academia Sinica) are appreciated for financing part of research of the first author.

\section{References}

A ZM, Yue SJ, Liu Y, Wei H (2006) Geochemical features of Early Carboniferous volcanites from the Chabuchaer Mountain, Yili region, Xinjiang. Xinjiang Geol 24(3):244-248

Allen MB, Vincent SJ (1997) Fault reactivation in the Junggar region, northwest China: the role of basement structures during Mesozoic-Cenozoic compression. J Geol Soc Lond 154:151-155

Allen MB, Windley BF, Zhang C (1993) Palaeozoic collisional tectonics and magmatism of the Chinese Tien Shan, Central Asia. Tectonophysics 220:89-115

Allen MB, Sengör AMC, Natal'in BA (1995) Junggar, Turfan and Alakol basins as Late Permian to ?Early Triassic extensional structures in a sinistral shear zone in the Altaid orogenic collage, Central Asia. J Geol Soc Lond 152:327-338

Allen MB, Anderson L, Searle RC, Buslov M (2006) Oblique rift geometry of the West Siberian Basin: tectonic setting for the Siberian flood basalts. J Geol Soc Lond 163:901-904

Bazhenov ML, Burtman VS, Dvorova AV (1999) Permian paleomagnetism of the Tien Shan fold belt, Central Asia: Post-collisional rotation and deformation. Tectonophysics 312(24):303-329

Bazhenov ML, Collins AQ, Degtyarev KE, Levashova NM, Mikolaichuk AV, Pavlov VE, Van der Voo R (2003) Palaeozoic northward drift of the North Tianshan (Central Asia) as revealed by Ordovician and Carboniferous paleomagmatism. Tectonophysics 366:113-141

Black R, Liégeois JP (1993) Cratons, mobile belts, alkaline rocks and continental lithospheric mantle: the Pan-African testimony. J Geol Soc Lond 150:89-98

Bonin B (2004) Do coeval mafic and felsic magmas in post-collisional to within-plate regimes necessarily imply two contrasting, mantle and crustal, sources? A review. Lithos 78:1-24

Campbell IH (2001) Identification of ancient mantle plumes. In: Mantle plumes: their identification through time. Geological Society of American Special Paper, vol 352, pp 5-21 
Carroll AR, Graham SA, Hendrix MS, Ying D, Zhou D (1995) Late Palaeozoic tectonic amalgamation of NW China: sedimentary records of the northern Tarim, northwestern Turpan, and southern Junggar basins. Bull Geol Soc Am 107:571-594

Carroll AR, Graham SA, Chang E, McKnight CL (2001) Sinian through Permian tectonostratigraphic evolution of the northwestern Tarim basin, China. In: Hendrix MS, Davis $\mathrm{G}$ (eds) Palaeozoic and Mesozoic tectonic evolution of central and eastern Asia: from continental assembly to intracontinental deformation. Geological Society of American Memoir, vol 194, pp 47-69

Charvet J, Shu LS, Laurent-Charvet S (2007) Palaeozoic structural and geodynamic evolution of eastern Tianshan (NW China): welding of the Tarim and Junggar plates. Episodes 30(3):162-186

Che ZC, Liu L, Liu HF, Luo JH (1996) Review on the ancient Yili rift, Xinjiang, China. Acta Petrol Sin 12(3):478-490 (in Chinese with English abstract)

Chen JF, Chen DG, Li XM, Zhou TX, Foland KA (1994) K-Ar and ${ }^{40} \mathrm{Ar} /{ }^{39}$ Ar geochronology of granites from the Alataw Mountains, northwest Xinjiang, China. Acta Petrol Sin 10(2):184-192 (in Chinese with English abstract)

Chen CM, Lu HF, Jia D, Cai DS, Wu SM (1999) Closing history of the southern Tianshan oceanic basin, western China: an oblique collisional orogeny. Tectonophysics 302:23-40

Chen JF, Zhou TX, Xie Z, Zhang X, Guo XS (2000) Formation of positive $\mathrm{e}_{\mathrm{Nd}}(\mathrm{T})$ granitoids from the Alataw Mountains, Xinjiang, China, by mixing and fractional crystallization: implication for Phanernozoic crustal growth. Tectonophysics 328:53-67

Chen YJ, Liu YL, Bao JX, Zhang ZJ, Chen HY, Cai WJ, Helmstaedt H (2004a) Isotopic dating for the volcanic rocks of the Aikendaban formation in West Tianshan, China and its tectonic implication. J Mineral Petrol 24(1):52-55 (in Chinese with English abstract)

Chen YJ, Bao JX, Zhang ZJ, Liu YL, Chen HY, Cai WJ, Helmstaedt H (2004b) Tectonic setting and element geochemistry of the Aikendaban formation volcanic rocks in west Tianshan. J Mineral Petrol 24(3):36-45 (in Chinese with English abstract)

Cluzel D, Lee BJ, Cadet JP (1991) Indosinian dextral ductile fault system and synkinematic plutonism in the southwest of the Ogcheon belt (South Korea). Tectonophysics 194(12):131-151

Cluzel D, Lee BJ, Cadet JP (1994) Indosinian dextral ductile fault system and synkinematic plutonism in the southwest of the Ogcheon belt (South Korea) - reply. Tectonophysics 230(12):138-140

Coleman RG (1989) Continental growth of northwest China. Tectonics 8(3):621-635

Coulon C, Megartsi M, Fourcade S, Maury RC, Bellon H, Louni-Hacini A, Cotten J, Coutelle A, Hermitte D (2002) Post-collisional transition from calc-alkaline to alkaline volcanism during the Neogene in Oranie (Algeria): magmatic expression of a slab breakoff. Lithos 
Cui ZL, Mei ZC, Qu HJ, Chen SY, Zheng GQ, Yang L, Liu JX, Wu YH, Xiong LP (1996) A study on the Upper Permian of the Yily Basin, Xinjiang. Geol J Univ 2(3):332-338 (in Chinese with English abstract)

de Jong K, Wang B, Faure M, Shu LS, Cluzel D, Charvet J, Ruffet G, Chen Y (2008) New 40Ar/39Ar age constraints on the Late Palaeozoic tectonic evolution of the western Tianshan (Xinjiang, northwestern China), with emphasis on late Permian fluid ingress. In: Xiao WJ, Kroner A, Windley BF (eds) Geodynamic evolution of Central Asia in the Palaeozoic and Mesozoic. International Journal of Earth Sciences. http://dx.doi.org/10.1007/s00531-0080338-8 (this volume)

D'lemos RS, Brown M, Strachan RA (1992) Granite magma generation, ascent and emplacement within a transpressional orogen. J Geol Soc Lond 149:487-490

Dobretsov NL, Berzin NA, Buslov MM (1995) Opening and tectonic evolution of the PaleoAsian Ocean. Int Geol Rev 37:335-360

Duggen S, Hoernle K, van den Bogaard P, Garbe-Schonberg D (2005) Postcollisional transition from subductionto intraplate-type magmatism in the westernmost Mediterranean: evidence for continental-edge delamination of subcontinental lithosphere. J Petrol 46:11551201

Gao J, Klemd R (2003) Formation of HP-LT rocks and their tectonic implications in the western Tianshan Orogen, NW China: geochemical and age constraints. Lithos 66:1-22

Gao J, Li MS, Xiao XC, Tang YQ, He GQ (1998) Palaeozoic tectonic evolution of the Tianshan orogen, northwestern China. Tectonophysics 287:213-231

Gao J, Long LL, Qian Q, Huang DZ, Su W, Klemd R (2006) South Tianshan: a Late Palaeozoic or a Triassic orogen? Acta Petrol Sin 22(5):1049-1061 (in Chinese with English abstract)

Guo X, Zhu YF (2006) Petrological and geochemical characteristics of the Carboniferous volcanic rocks, South of the Xinyuan County, Xinjiang. Geol J China Univ 12(1):62-73 (in Chinese with English abstract)

Hamrabaev IH, Simon AK (1984) Evolutzia magmatizma Sredney Azii (the evolution of magmatism in Central Asia). Nauka Press, Moscow, p 276 (in Russian)

Han CM, Xiao WJ, Zhao GC, Mao JW, Yang JM, Wang ZL, Yan Z, Mao QQ (2006)

Geological characteristics and genesis of the Tuwu porphyry copper deposit, Hami, Xinjiang, Central Asia. Ore Geol Rev 29:77-94

Hofmann AW, Jochum KP, Seufert M, White WM (1986) Nb and Pb in oceanic basalts: new constraints on mantle evolution. Earth Planet Sci Lett 79:33-45

Hutton DHW, Reavy RJ (1992) Strike-slip and granite petrogenesis. Tectonics 11:960-967 
Jahn BM (2004) The Central Asian Orogenic Belt and growth of the continental crust in the Phanerozoic. Geol Soc Spec Publ 226:73-100

Jahn BM, Griffin WL, Windley BF (2000) Continental growth in the Phanerozoic: evidence from Central Asia. Tectonophysics 328:1-227

Jahn BM, Windley BF, Natal'in B, Dobretsov N (2004) Phanerozoic continental growth in Central Asia. J Asian Earth Sci 23:599-815

Jiang CY, Mu YM, Bai KM, Zhao XN, Zhang HB, Hei AZ (1999) Chronology, petrology, geochemistry and tectonic environment of granitoids in the southern Tianshan Mountain, western China. Acta Petrol Sin 15(2):298-308 (in Chinese with English abstract)

Klemd R, Bröcker M, Hacker BR, Gao J, Gans P, Wemmer K (2005) New age constraints on the metamorphic evolution of the high-pressure/low-temperature belt in the Western Tianshan Mountains, NW China. J Geol 113:157-168

Laurent-Charvet S, Charvet J, Shu LS, Ma R, Lu HF (2002) Palaeozoic late collisional strikeslip deformations in Tianshan and Altay, eastern Xinjiang, NW China. Terra Nova 14(4):249256

Laurent-Charvet S, Charvet J, Monie P, Shu LS (2003) Late Palaeozoic strike-slip shear zones in eastern Central Asia (NW China): new structural and geochronological data. Tectonics 22(2):1099-1101

Li WP, Jiang CY, Xie GC, Wu WK (1995) Geologic features for granites of the variscian early period on the Beluohonu Caledonia fold belt. J Xi' an College Geol 17(4):1-7 (in Chinese with English abstract)

Li HQ, Xie CF, Chang HL, Cai H, Zhu JP, Zhou S (1998) Study on metallogenetic chronology of nonferrous and precious metallic ore deposts in north Xinjiang, China. Geology Publishing house, Beijing, pp 100-127 (in Chinese with English abstract)

Li WP, Wang T, Li JB, Kang X, Yu FS, Han QJ, Ma ZP (2001) Petrology, geochemistry of Hercynian granites of Hongliuhe area and its tectonic setting in Eastern Tianshan Mountains, Western China. Geol Rev 47(4):368-376 (in Chinese with English abstract)

Li YJ, Wang ZM, Wu HR, Huang ZB, Tan ZJ, Luo JC (2002) Discovery of radiolarian fossils from the Aiketik group at the western end of the South Tianshan Mountains of China and its implications. Acta Geol Sin 76(2):146-154

Li YJ, Sun LD, Wu HR, Zhang GY, Wang GL, Huang ZB (2005) Permo-Carboniferous radiolarians from the Wupata'erkan group, Western South Tianshan, Xinjiang, China. Acta Geol Sin 79(1):16-23

Li JY, Wang KZ, Sun GH, Mo SG, Li WQ, Yang TN, Gao LM (2006a) Palaeozoic active margin slices in the southern Turfan-Hami basin: geological records of subduction of the Paleo-Asian Ocean plate in central Asian regions. Acta Petrol Sin 22(5):1087-1102 (in Chinese with English abstract) 
Li ZC, Li YJ, Li JH, Luan XD, Guo WJ (2006b) Geochemical characteristics of the Dahalajunshan formation volcanic rocks and their implications on the tectonic setting in Awulale area. Xinjiang Geol 24(2):120-124 (in Chinese with English abstract)

Liégeois JP, Navez J, Hertogen J, Black R (1998) Contrasting origin of post-collisional high$\mathrm{K}$ calc-alkaline and shoshonitic versus alkaline and peralkaline granitoids. The use of sliding normalization. Lithos 45:1-28

Liu BP, Wang ZQ, Zhang CH, Ma HW, Zhou HR, Zhu H, Gong YM, Jia WM (1996) The tectonic framework and evolution in Southwest Tianshan Mountains, China. China University of Geosciences Press, Wuhan, pp 1-120 (in Chinese)

Liu ZQ, Han BF, Ji JQ, Li ZH (2005) Ages and geochemistry of the post-collisional granitic rocks from Eastern Alataw Mountains, Xinjiang, and implications for vertical crustal growth. Acta Petrol Sin 21(3):623-639 (in Chinese with English abstract)

Liu J, Li YJ, Wang XG, Guo WJ (2006) Geochemical Charactersitics and tectonic environment of the Yishijilike formation volcanic rocks in the Awulale area of western Tianshan. Xinjiang Geol 24(2):105-108 (in Chinese with English abstract)

Lustrino M, Morra V, Fedele L, Serracino M (2007) The transition between orogenic and anorogenic magmatism in the western Mediterranean area: the Middle Miocene volcanic rocks of Isola del Toro (SW Sardinia, Italy). Terra Nova 19:148-159

Ma RZ, Wang RM (2000) Paleo-volcanic apparatus and its controlling on mineralization in Axi gold field of Xinjiang. Xinjing Geol 18(3):229-235

Mao J, Konopelko D, Seltmann R, Lehmann B, Chen W, Wang Y, Eklund O, Usubaliev T (2004) Postcollisional age of the Kumtor Gold deposit and timing of Hercynian events in the Tien Shan, Kyrgyzstan. Econ Geol Bull Soc Econ Geol 99:1771-1780

Njanko T, Nédélec A, Affaton A (2006) Synkinematic high-K calcalkaline plutons associated with the Pan-African Central Cameroon shear zone (W-Tibati area): petrology and geodynamic significance. J Afr Earth Sci 44:494-510

Oyhantçabal P, Siegesmund S, Wemmer K, Frei R, Layer P (2007) Post-collisional transition from calc-alkaline to alkaline magmatism during transcurrent deformation in the southernmost Dom Feliciano Belt (Braziliano-Pan-African, Uruguay). Lithos. doi:10.1016/j.lithos.2007.03.001

Pearce JA (1982) Trace element characteristics of lavas from destructive plate boundaries. In: Thorpe RS (ed) Andesites: Orogenic Andesites and related rocks. Wiley, Chichester, pp 525548

Plank T (2005) Constraints from thorium/lanthanum on sediment recycling at subduction zones and the evolution of the continents. J Petrol 46:921-944

Qian Q, Gao J, Xiong XM, Long LL, Huang DZ (2006) Petrogenesis and tectonic settings of Carboniferous volcanic rocks from north Zhaosu, western Tianshan Mountains: constraints 
from petrology and geochemistry. Acta Petrol Sin 22(5):1307-1323 (in Chinese with English abstract)

Rickwood PC (1989) Boundary lines within petrologic diagrams which use oxides of major and minor elements. Lithos 22:247-263

Rosenberg CL (2004) Shear zones and magma ascent: a model based on a review of the Tertiary magmatism in the Alps. Tectonics 23:1-21

Saint Blanquat M, De Tikoff B, Teyssier C, Vigneresse JL (1998) Transpressional kinematics and magmatic arcs. In: Holdsworth RE, Strachan RA, Dewey JF (eds) Continental transpressional and transtensional tectonics. Geol Soc Lond Spec Publ 135:327-340

Shao TQ, Shi Y, Jin H, Song Y, Zhu ZX, Wang KZ, Zhan JD, Xu D (2006) Volcanic rock petrochemical characteristics of the Dahalajunshan formation in the western Tianshan, Xinjiang and their geological significance. Xinjiang Geol 24(3):218-222 (in Chinese with English abstract)

Shu LS, Zhu WB, Wang B, Faure M, Charvet J, Cluzel D (2005) The post-collision intracontinental rifting and olistostrome on the southern slope of Bogda Mountains, Xinjiang. Acta Petrol Sin 21(1):25-36 (in Chinese with English abstract)

Solomovich LI (2007) Postcollisional magmatism in the South Tien Shan Variscan Orogenic Belt, Kyrgyzstan: evidence for high-temperature and high-pressure collision. J Asian Earth Sci 30(1):142-153

Solomovich LI, Trifonov BA (2002) Postcollisional granites in the South Tien Shan Variscan Collisional Belt, Kyrgyzstan. J Asian Earth Sci 21(1):7-21

Steenken A, Siegesmund S, Heinrichs T (2000) The emplacement of the Rieserferner Pluton (Eastern Alps, Tyrol): constraints from field observations, magmatic fabrics and microstructures. J Struct Geol 22:1855-1873

Sun SS, McDonough WF (1989) Chemical and isotopic systematics of ocean island basalts: implications for mantle composition and processes. In: Saunders AD, Norry MJ (eds) Magmatism in the Ocean Basins. Geol Soc Lond Spec Publ, vol 42, pp 313-345

Sun GH, Li JY, Wang DG, Gao LM, Song AJ (2006) Zircon SHRIMP U-Pb ages of granite and granodiorite at the south side of the Aqqikkuduk fault, East Tianshan, Xinjiang, China, and its tectonic implications. Geol Bull China 25(8):945-952 (in Chinese with English abstract)

Tommasi A, Vauchez A, Fernandes LAD, Porcher CC (1994) Magma-assisted strain localization in an orogen-parallel transcurrent shear zone of southern Brazil. Tectonics $13: 421-437$

Tribe IR, D'lemos RS (1996) Significance of a hiatus in down-temperature fabric development within syn-tectonic quartz diorite complexes, Channel Islands, UK. J Geol Soc 153(1):127-138 
Van der Voo R, Levashova NM, Skrinnik LI, Kara TV, Bazhenov ML (2006) Late orogenic, large-scale rotations in the Tien Shan and adjacent mobile belts in Kyrgyzstan and Kazakhstan. Tectonophysics 426(3-4):335-360

Vavra G, Gebauer D, Schmid R, Compston W (1996) Multiple zircon growth and recrystallization during polyphase Late Carboniferous to Triassic metamorphism in granulites of the Ivrea Zone (Southern Alps): an ion microprobe (SHRIMP) study. Contrib Mineral Petrol 122:337-358

Wang CL, Wei HM, Sun JD, Wang QQ, Yu FC (1993) Genetic types of the variscan depositscontrolling granites in northern Boluohuoluo Mountains. J Xi' an College Geol 15(4):74-79 (in Chinese with English abstract)

Wang BY, Lang ZJ, Li XD (1994) Study on the geological sections across the western segment of Tianshan Mountains, China. Science Press, Beijing, pp 5-19

Wang Q, Zhao ZH, Bai ZH, Bao ZW, Xu JF, Xiong XL, Mei HJ, Wang YX (2003) Carboniferous adakites and $\mathrm{Nb}$-enriched arc basaltic rocks association in the Alataw Mountains, north Xinjiang: interactions between slab melt and mantle peridotite and implications for crustal growth. Chin Sci Bull 48(19):2108-2115

Wang CY, Yang ZE, Luo H, Mooney WD (2004) Crustal structure of the northern margin of the eastern Tien Shan, China, and its tectonic implications for the 1906 M 7.7 Manas earthquake. Earth Planet Sci Lett 223:187-202

Wang B, Faure M, Cluzel D, Shu LS, Charvet J, Meffre S (2006a) Late Palaeozoic tectonic evolution of the northern West Tianshan, NW China. Geod Acta 19(3-4):237-247

Wang Q, Zhao ZH, Xu JF, Wyman DA, Xiong XL, Zi F, Bai ZH (2006b) Carboniferous adakite-high-Mg andesite-Nb-enriched basaltic rock suites in the Northern Tianshan area: Implications for Phanerozoic crustal growth in the Central Asia Orogenic Belt and $\mathrm{Cu}-\mathrm{Au}$ mineralization. Acta Petrol Sin 22(1):11-30

Wang B, Shu LS, Cluzel D, Faure M, Charvet J (2007a) Geochemical Constraints on Carboniferous Volcanic rocks of Yili Block (Xinjiang, NW China); implication on tectonic evolution of Western Tianshan. J Asian Earth Sci 29:148-159

Wang B, Chen Y, Zhan S, Shu LS, Faure M, Cluzel D, Charvet J, Laurent-Charvet S (2007b) Primary Carboniferous and Permian paleomagnetic results from Yili Block and their geodynamic implications on evolution of Chinese Tianshan Belt. Earth Planet Sci Lett 263:288-308

Wang B, Shu LS, Faure M, Cluzel D, Charvet J (2007c) Paleozoic tectonism and magmatism of Kekesu-Qiongkushitai section in southwestern Chinese Tianshan and their constraints on the age of the orogeny. Acta Petrol Sin 23(6):1354-1368 (in Chinese with English abstract)

Wartes MA, Carroll AR, Greene TJ (2002) Permian sedimentary record of the Turpan-Hami basin and adjacent regions, northwest China: constraints on postamalgamation tectonic 
evolution. Geol Soc Am Bull 114:131-152

Weinberg RF, Sial AN, Mariano G (2004) Close spatial relationship between plutons and shear zones. Geology 32:377-380

Windley BF, Allen MB, Zhang C, Zhao ZY, Wang GR (1990) Palaeozoic accretion and Cenozoic redeformation of the Chinese Tien Shan range, Central Asia. Geology 18:128-131

Windley BF, Alexeiev D, Xiao WJ, Kroner A, Badarch G (2007) Tectonic models for accretion of the Central Asian Orogenic Belt. J Geol Soc Lond 164:31-47

XBGMR (Xinjiang Bureau of Geology and Mineral Resources) (1959) geological map 1:200000, Kumux sheet (K-45-17)

XBGMR (Xinjiang Bureau of Geology and Mineral Resources) (1973) geological map 1:200000, Tuokuzi-Kuma-Lake sheet (K-45-1)

XBGMR (Xinjiang Bureau of Geology and Mineral Resources) (1975) geological map 1:200000, Xinyuan sheet (K-44-6)

XBGMR (Xinjiang Bureau of Geology and Mineral Resources) (1979) geological map 1:200000, Zhaosu sheet (K-44-10)

XBGMR (Xinjiang Bureau of Geology and Mineral Resources) (1993) Regional geology of Xinjiang Uygur Autonomy Region. Geology Publishing House, Beijing, pp 1-841 (in Chinese with English abstract)

Xia LQ, Xia ZC, Xu XY, Li XM, Ma ZP, Wang LS (2004a) Carboniferous Tianshan igneous megaprovince and mantle plume. Geol Bull China 23(9-10):903-910 (in Chinese with English abstract)

Xia LQ, Xu XY, Xia ZC, Li XM, Ma ZP, Wang LS (2004b) Petrogenesis of Carboniferous rift-related volcanic rocks in the Tianshan, northwestern China. Geol Soc Am Bull 116(34):419-433

Xia LQ, Li XM, Xia ZC, Xu XY, Ma ZP, Wang LS (2006) Carboniferous-Permian rift-related volcanism and mantle Plume in the Tianshan, Northwestern China. Northwest Geol 39(1):149

Xiao WJ, Zhang LC, Qin KZ, Sun S, Li JL (2004) Palaeozoic accretionary and collisional tectonics of the eastern Tianshan (China): implications for the continental grouth of Central Asia. Am J Sci 304:370-395

Xiao WJ, Han CM, Yuan C, Chen HL, Sun M, Lin SF, Li ZL, Mao QG, Zhang JE, Sun S, Li JL (2006) Unique Carboniferous-Permian tectonic-metallogenic framework of Northern Xinjiang (NW China): constraints for the tectonics of the southern Paleoasian Domain. Acta Petrol Sin 22(5):1062-1076 (in Chinese with English abstract) 
Xiong XL, Zhao ZH, Bai ZH, Mei HJ, Xu JF, Wang Q (2001) The origin of Awulale sodiumrich adakitic rocks in western Tien Shan; constraints for $\mathrm{Nd}$ and $\mathrm{Sr}$ isotopic composition. Acta Petrol Sin 17(4):514-522

Xu XY, Ma ZP, Xia ZC, Xia LQ, Li XM, Wang LS (2006) TIMS U-Pb isotopic dating and geochemical characteristics of Palaeozoic granitic rocks from the Middle-Western section of Tianshan. Northwest Geol 39(1):50-75 (in Chinese with English abstract)

Yakubchuk A (2004) Architecture and mineral deposit settings of the Altaid orogenic collage: a revised model. J Asian Earth Sci 23:761-779

Yang JZ, Zhao YL, Wang YJ, Jiang XW (2003) Sedimentary environment and mineralization of Dahalajunshan formation in west Tianshan orogenic belt, Xinjiang. Geol Prospect 39(2):15

Yin A, Nie SY (1996) A Phanerozoic palinspastic reconstruction of China and its neighboring regions. In: Yin A, Harrison M (eds) The Tectonic evolution of Asia. Cambridge University Press, Rubey Colloquium, Cambridge, pp 442-485

Zhai W, Sun XM, Gao J, He XP, Liang JL, Miao LC, Wu YL (2006) SHRIMP dating of zircons from volcanic host rocks of Dahalajunshan formation in Axi gold deposit, Xinjiang, China, and its geological implications. Acta Petrol Sin 22(5):1399-1404 (in Chinese with English abstract)

Zhang JS, Li ZC (2006) Tectonic setting of the Dahalajunshan formation volcanic rocks in Awulale of west Tianshan. Gansu Geol 15(2):10-14 (in Chinese with English abstract)

Zhang C, Zhai MG, Allen MB, Saunders AD, Wang GR, Huang X (1993) Implications of Palaeozoic ophiolites from Western Junggar, NW China, for the tectonics of central Asia. J Geol Soc 150:551-561

Zhang LF, Ai YL, Li XP, Rubatto D, Song B, Williams S, Song SG, Ellis DJ, Liou JG (2007) Triassic collision of western Tianshan orogenic belt, China: evidence from SHRIMP U-Pb dating of zircon from HP/UHP eclogitic rocks. Lithos 96:266-280

Zhao JM, Liu GD, Lu ZX, Zhang XK, Zhao GZ (2003a) Lithospheric structure and dynamic processes of the Tianshan orogenic belt and the Junggar basin. Tectonophysics 376:199-239

Zhao ZH, Bai ZH, Xiong XL, Mei HJ, Wang YX (2003b) ${ }^{40} \mathrm{Ar} /{ }^{39} \mathrm{Ar}$ chronological study of Late Palaeozoic volcanic-hypabyssal igneous rocks in western Tianshan, Xinjiang. Geochimica 32:317-327 (in Chinese with English abstract)

Zhao ZH, Wang Q, Xiong XL, Zhang HX, Niu HC, Xu JF, Bai ZH, Qiao YL (2006) Two types of adakites in north Xinjiang, China. Acta Petrol Sin 22(5):1249-1265 (in Chinese with English abstract)

Zhou TX, Zhang X, Chen DG, Li XM, Li BX, Yin CS (1994) Major element geochemistry of granitoids from Alatao Mountain, Xinjiang, China. Earth Sci J China Univ Geosci 19(2):149156 
Zhou TX, Chen JF, Li XM (1995) Tectonic environment and origin of granitoids from Alatao Mountain, Xinjiang, China. Acta Petrol Sin 11(4):386-396

Zhou TX, Chen JF, Li XM (1996) Origin of high eNd(t) granites from Alatao Mountain, Xinjiang. Sci Geol Sin 31(1):71-79

Zhou D, Graham SA, Chang EZ, Wang BY, Hacker B (2001) Palaeozoic tectonic amalgamation of the Chinese Tianshan: Evidence from a transect along the Dushanzi-Kuqa highway. In: Hendrix MS, Davis GA (eds) Palaeozoic and Mesozoic tectonic evolution of central Asia: from continental assembly to intracontinental deformation. Boulder, Colorado, Geological Society of American Memoir, vol 194, pp 23-46

Zhu YF, Zhang LF, Gu LB, Guo X, Zhou J (2005) The zircon SHRIMP chronology and trace element geochemistry of the Carboniferous volcanic rocks in western Tianshan Mountains. Chin Sci Bull 50(19):2201-2212

Zhu YF, Zhou J, Guo X (2006a) Petrology and Sr-Nd isotopic geochemistry of the Carboniferous volcanic rocks in the western Tianshan Mountains, NW China. Acta Petrol Sin 22(5):1341-1350 (in Chinese with English abstract)

Zhu YF, Zhou J, Song B, Zhang LF, Guo X (2006b) Age of the "Dahalajunshan" formation in Xinjiang and its disintegration. Geol Chin 33(3):487-497 (in Chinese with English abstract) 


\section{Figures}

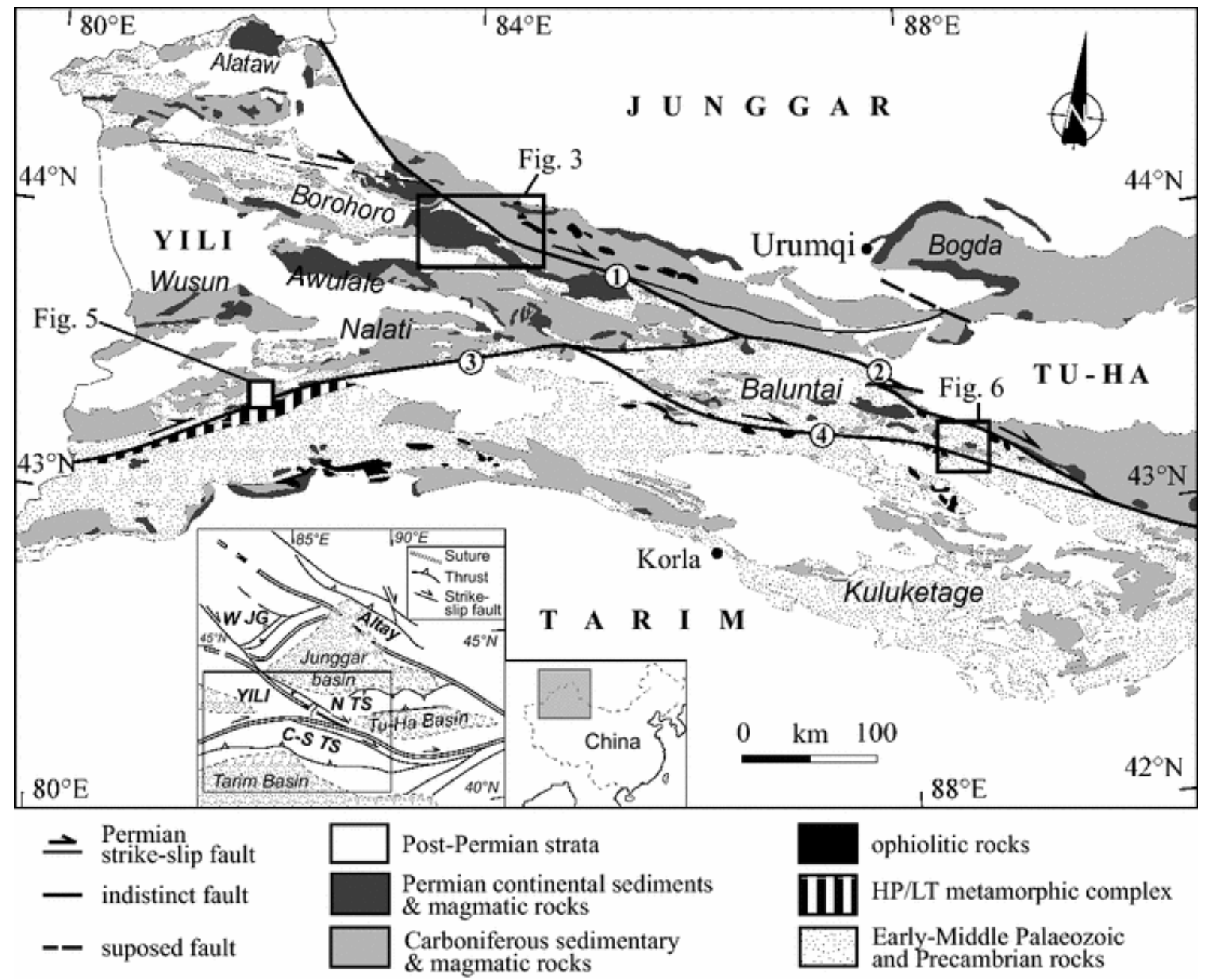

Fig. 1 Simplified sketch map of the western Chinese Tianshan Belt (modified from XBGMR 1993; insets after Zhang et al. 1993, Allen and Vincent 1997), showing the occurrences of Carboniferous to Permian igneous rocks and the main wrench faults. Numbers $1-4$ correspond to the main faults, 1 North Tianshan Fault (NTF), 2 Main Tianshan Shear Zone (MTSZ), 3 Qingbulak-Nalati Fault (QNF), 4 Sangshuyuanzi Fault (SF), W JG Western Junggar, $N$ TS North Tianshan, $C-S T S$ Central-South Tianshan 


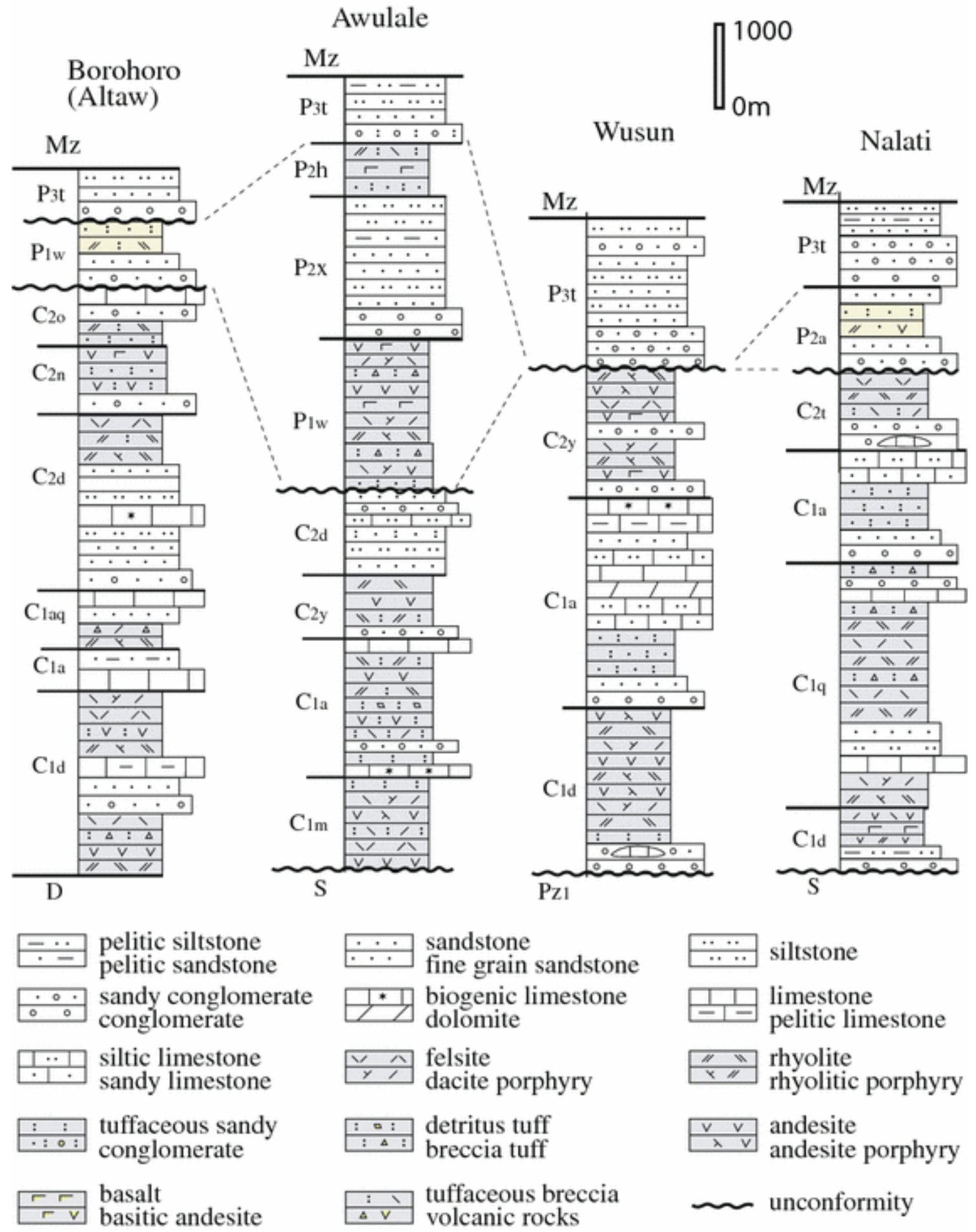

Fig. 2 Simplified stratigraphic columns of Carboniferous-Permian volcanic and sedimentary rocks in northwestern Chinese Tianshan (modified from 1:200,000 geological maps of Xinjiang region). Abbreviations of formations: $C_{1} d$ lower Carboniferous Dahalajunshan Fm., $C_{1} m$ Meiluokahe Fm., $C_{1} q$ Qiergustao Fm., $C_{1} a$ Akeshake Fm., $C_{1} a q$ Aqialehe Fm., $C_{2} y$ upper Carboniferous Yishijilike Fm., $C_{2} d$ Dongtujin Fm., $C_{2} n$ Naogaitu Fm., $C_{2} o$ Oyiman Fm., $C_{2} t$ Tuergong Fm., $P_{1} w$ lower Permian Wulang Fm., $P_{2} x$ Xiaoshansayi Fm., $P_{2} h$ Hamist Fm., $P{ }_{2} a$ Aikendaban Fm., $P{ }_{3} t$ Tielimuke Fm, $D$ Devonian, $S$ Silurian, $P z_{1}$ Early Palaeozoic strata, $M z$ Mesozoic strata 


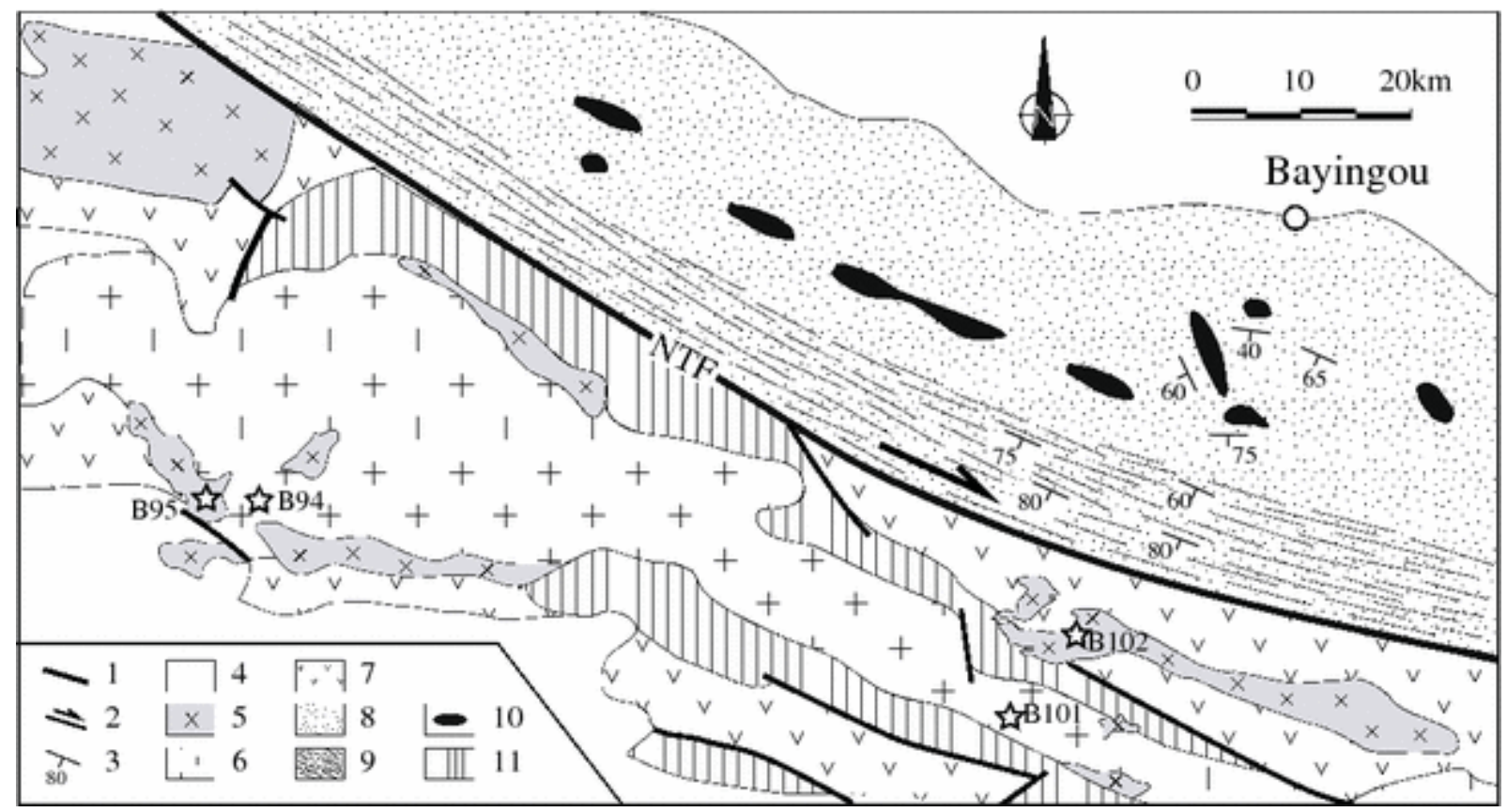

Fig. 3 Structural sketch maps of Borohoro area (modified from XBGMR 1973, 1975), showing the spatial relationship of granitic plutons with ductile dextral North Tianshan Fault. For location, see Fig. 1. The sampling localities are marked with open pentacles followed by sample numbers, and their GPS coordinates are listed in Table 21 fault, 2 North Tianshan Fault zone, 3 foliation/bedding and dip angle, 4 Meso-Cenozoic, 5 Permian pink granite, 6 Permian dark granite, 7 Early Carboniferous volcaniclastic rocks, 8 weakly deformed Carboniferous turbitite, 9 mylonitic and metamorphic turbitite, 10 blocks of ultra-mafic rocks, 11 Silurian-Devonian undeformed sedimentary rocks 

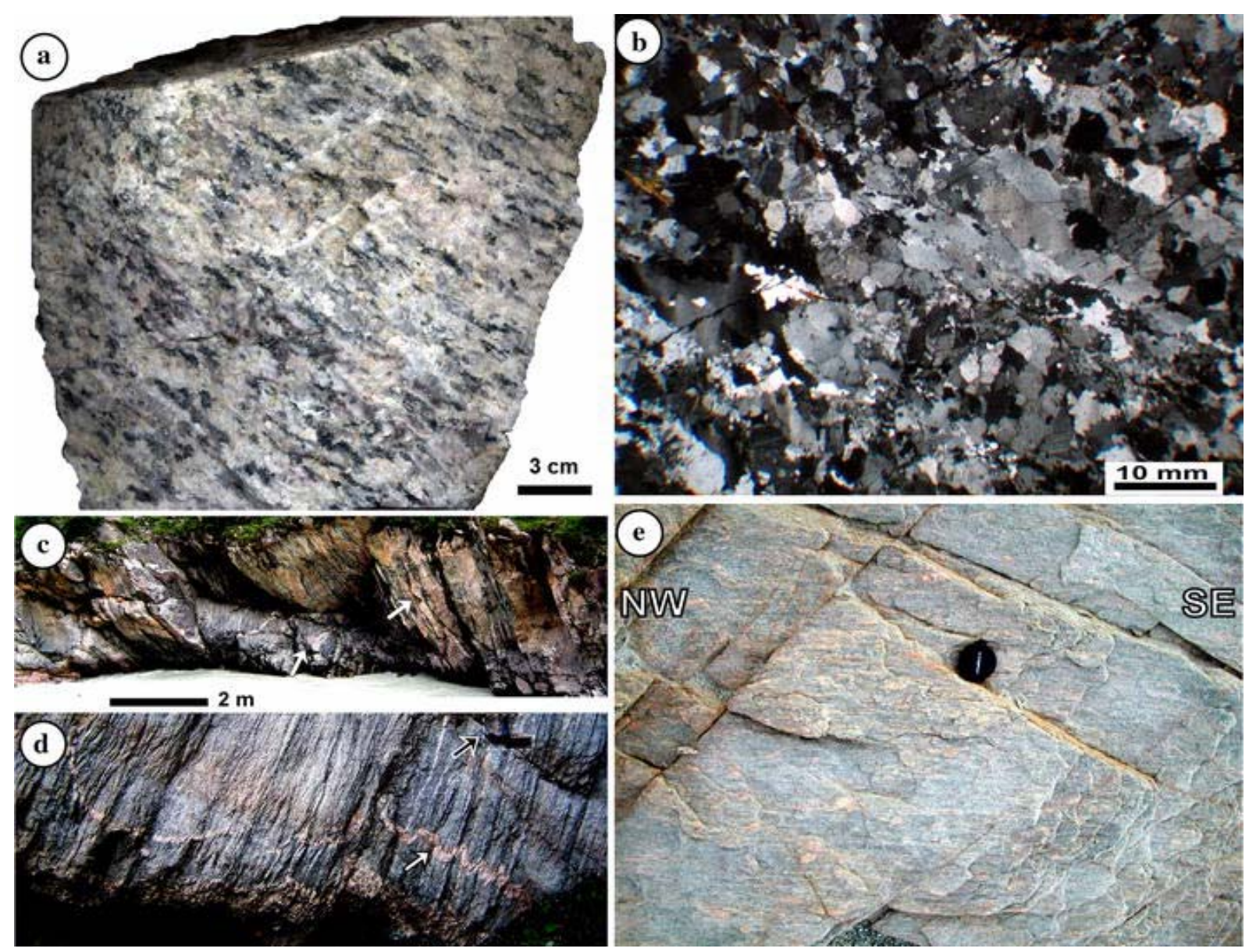

Fig. 4 a Photograph of hand specimen of Borohoro biotite K-granite showing the linear fabric defined by alignment of biotite, hornblende, feldspar and elongated quartz, and the planar fabric marked by ribbons of mafic minerals; $\mathbf{b}$ microphotograph of Borohoro K-granite, pale grains are mostly quartz, feldspar and brown minerals are biotite and minor hornblende, dark grains are mainly extinct quartz and feldspar; c, d field photographs in Kekesu section showing boudinaged or folded K-granite dykes (directed by white arrows) intruding the mylonitic gabbro, black arrow in $\mathbf{d}$ shows the location of a hammer for scale; e mylonitized $\mathrm{K}$-granite in Gangou section, shallow dipping lineation included in sub-vertical SE extending foliation 


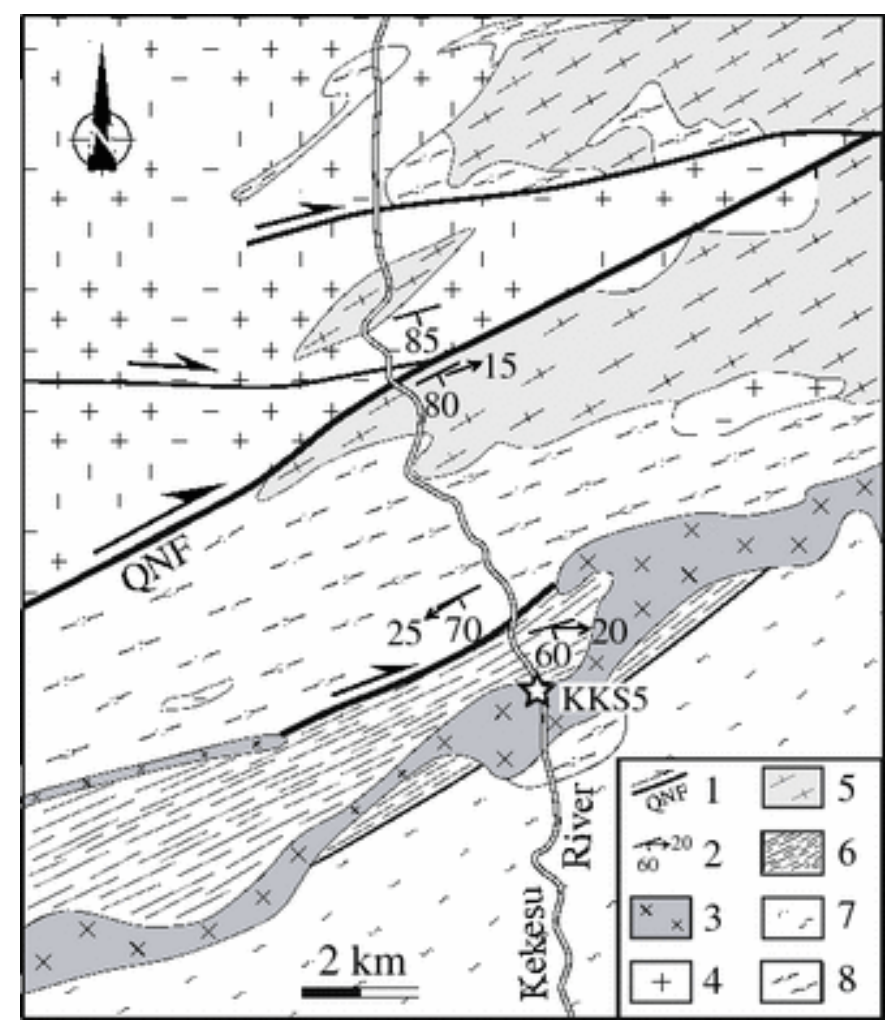

Fig. 5 Structural sketch map of Kekesu River section (modified from XBGMR 1979). For location, see Fig. 1. The sampling locality is marked with open pentacles followed by sample numbers, and reference Table 2 for the GPS coordinate. 1 Qingbulake-Nalati fault zone, 2 foliation with dip angle and lineation with pitch angle, 3 Permian A-type K-granite, 4 Carboniferous undeformed I-type granite, 5 Devonian?-Carboniferous strongly deformed granite and gabbro, 6 mylonite, 7 greenschist facies meta-sedimentary rocks, 8 Proterozoic gneiss 


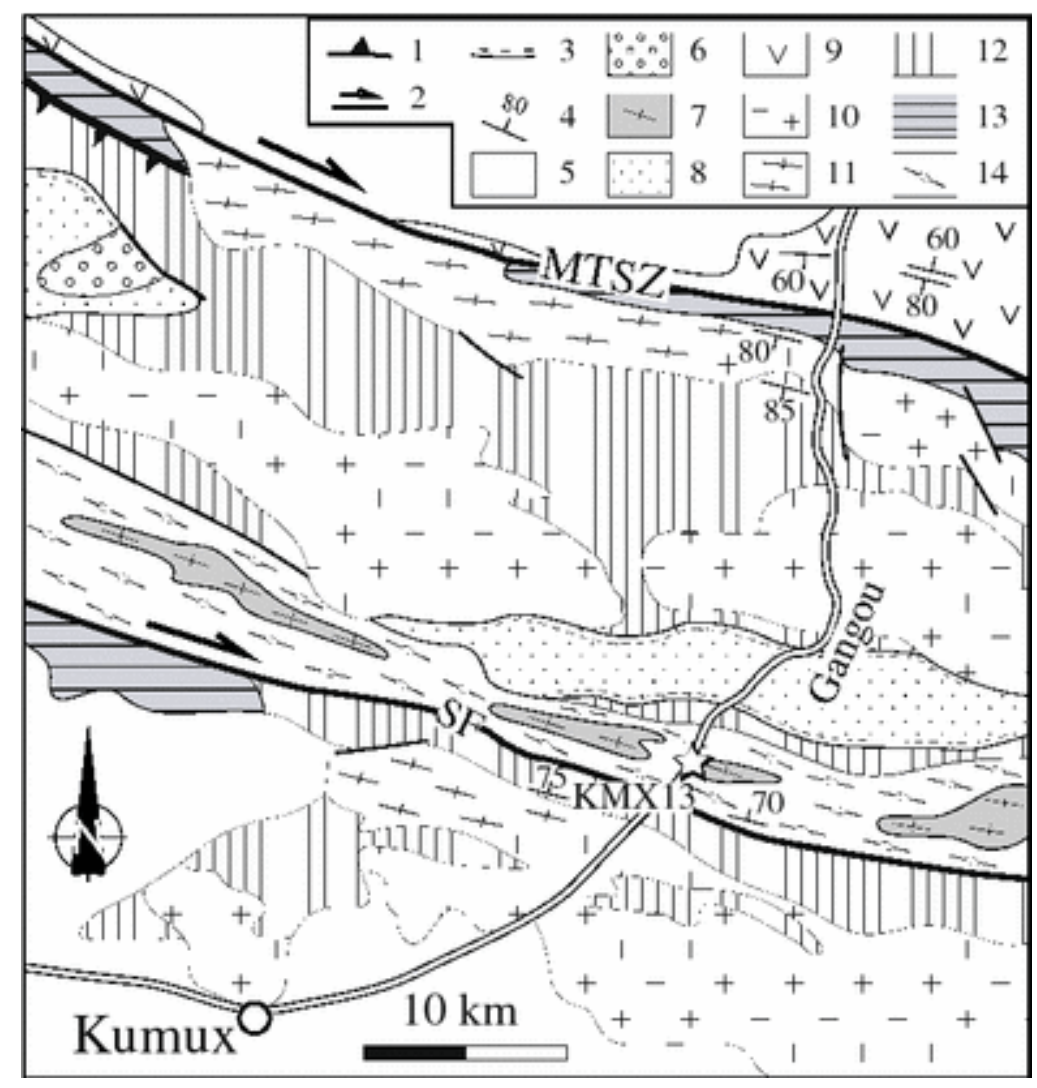

Fig. 6 Structural sketch map of Gangou section (modified from XBGMR 1959). For location, see Fig. 1. The sampling locality is marked with open pentacle followed by sample number, and the GPS coordinate can be found in Table 2. 1 Early Palaeozoic thrust, 2 strike-slip faults, where MTSZ refers to the Mains Tianshan Shear Zone, and SF represents the Sangshuyuanzi Fault, 3 unconformity, 4 foliation/bedding and dip angle, 5 Cenozoic, 6 Permian molassic deposits, 7 Permian foliated K-granite, 8 Carboniferous sedimentary rocks, 9 Carboniferous volcaniclastic rocks, 10 Early Palaeozoic undeformed granite, 11 Early Palaeozoic foliated granite, 12 Ordovician-Devonian rocks, 13 ophiolitic melange, 14 Proterozoic orthogneiss 

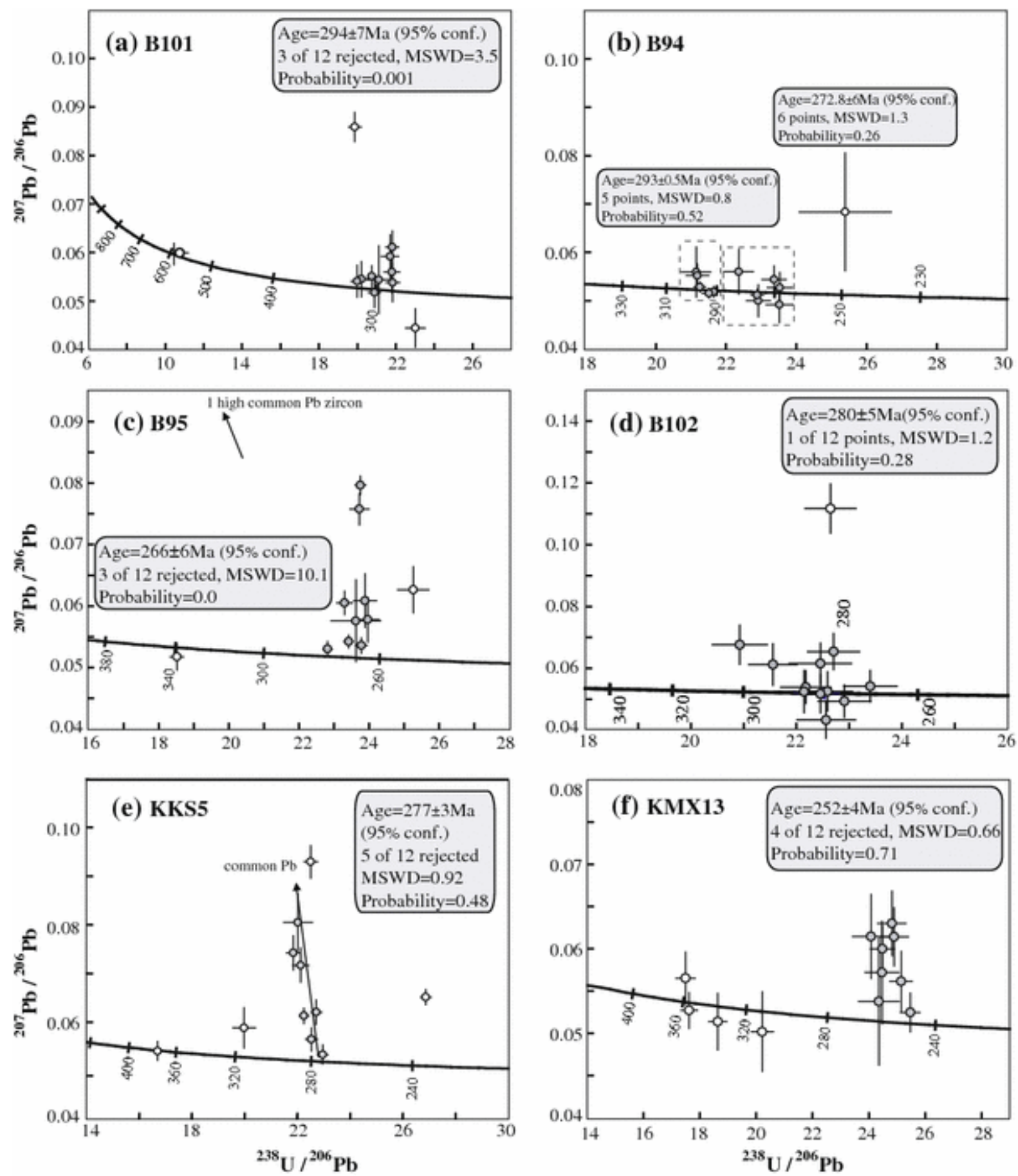

Fig. 7 Inversed Concordia diagrams of zircon U-Pb LA-ICPMS dating results on the granitoids from the Western Chinese Tianshan. Filled gray circles refer to the plots used to calculate the concordant ages, and open circles represent rejected plots 

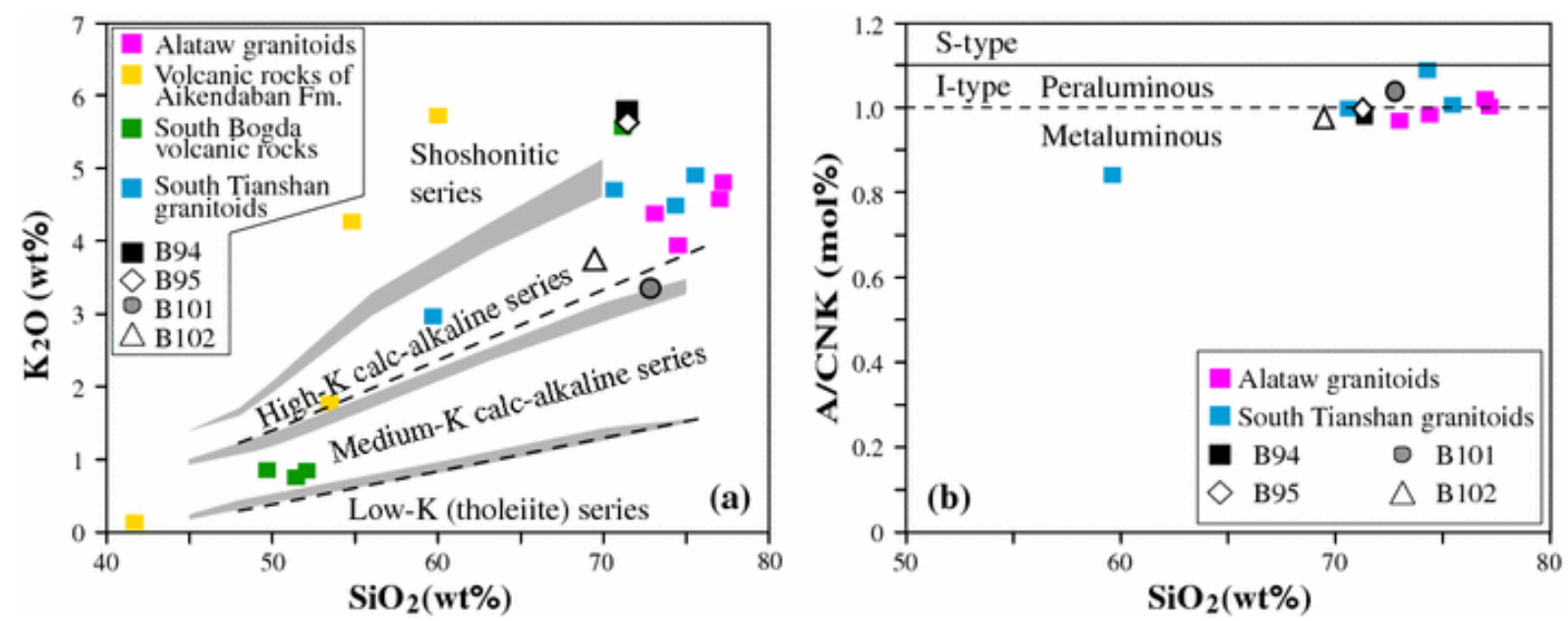

Fig. 8 a Classification of Permian magmatic rocks of the West Tianshan in the potassiumsilica diagram after Rickwood (1989); b compositional plots of the Permian granitic rocks of the West Tianshan in the $\mathrm{A} / \mathrm{CNK}$ (molecular ratio $\mathrm{Al}_{2} \mathrm{O}_{3} /\left[\mathrm{CaO}+\mathrm{Na}_{2} \mathrm{O}+\mathrm{K}_{2} \mathrm{O}\right]$ ) versus Silica diagram. See Table 3 for the references
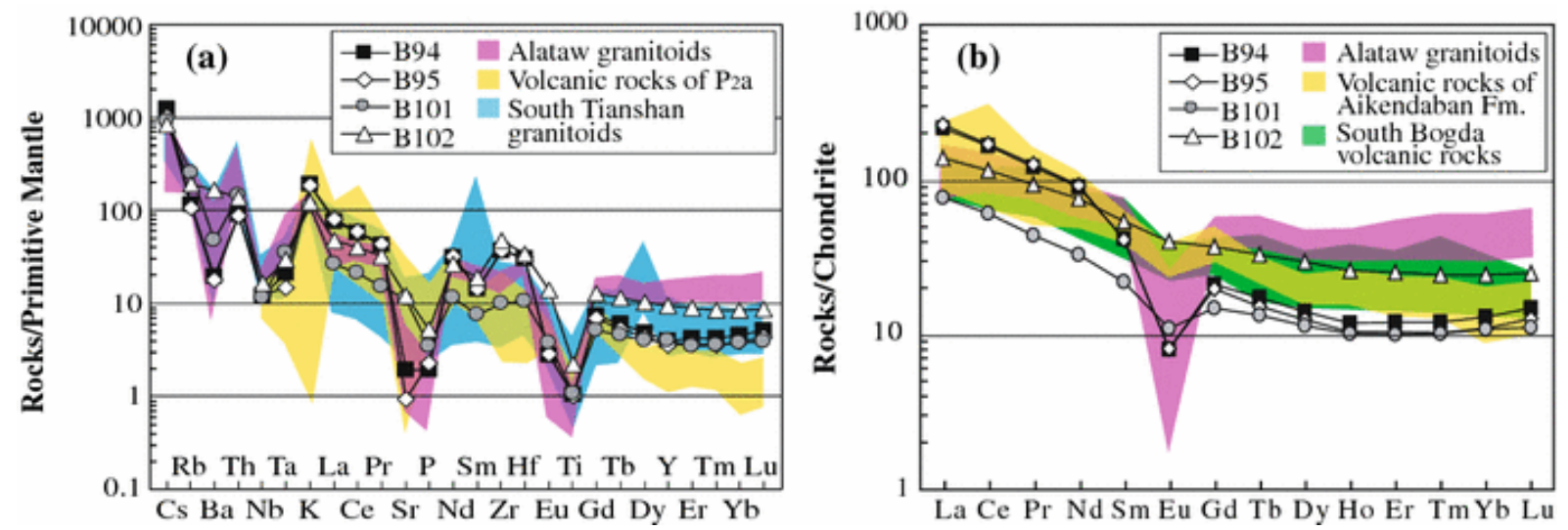

Fig. 9 a Primitive mantle normalized trace elements abundances and $\mathbf{b}$ Chondrite normalized rare earth elements patterns for the granitoids from the Borohoro plutons, northwestern Chinese Tianshan. Normalized values are after Sun and McDonough (1989). See Table 3 for references 

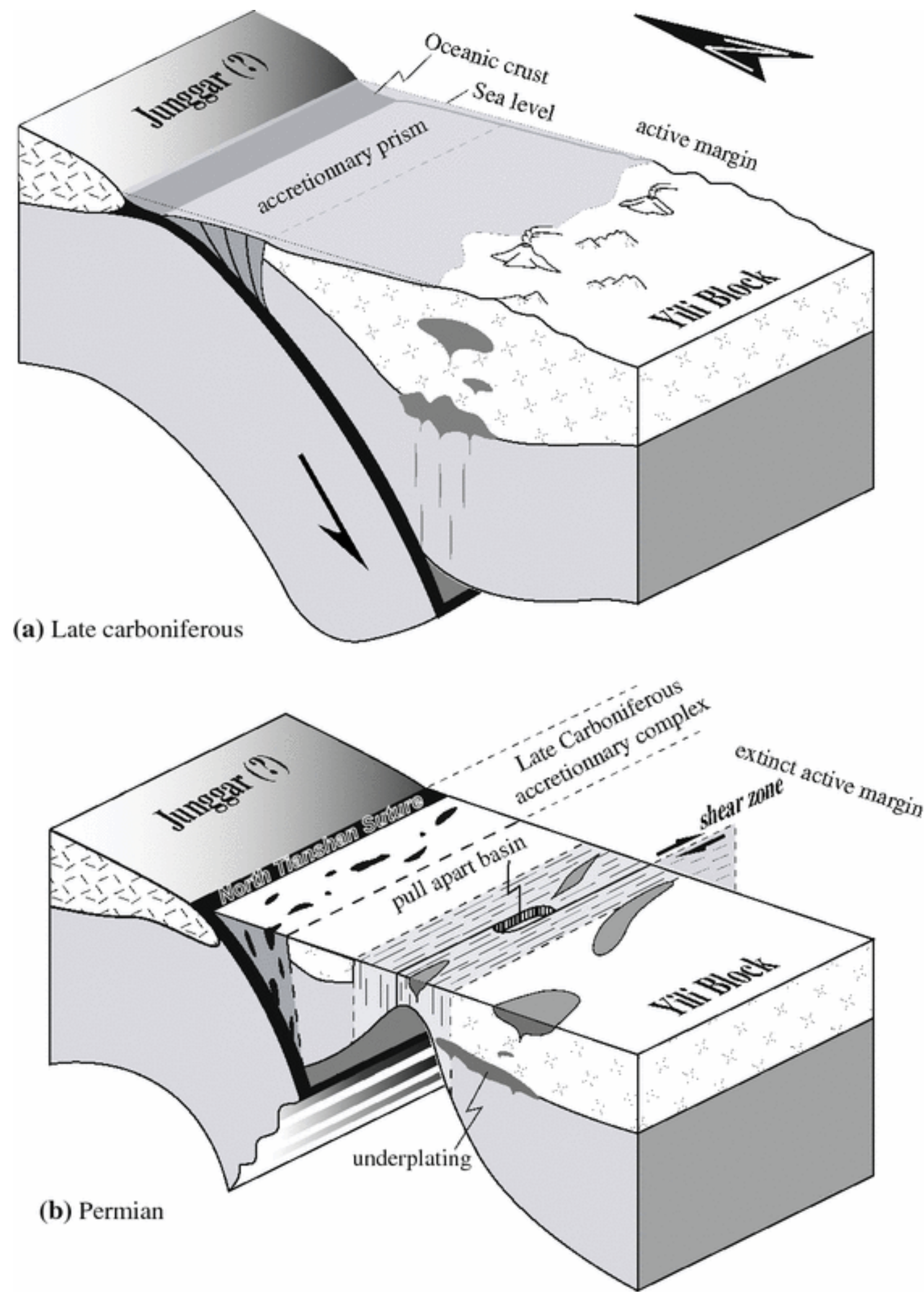

Fig. 10 Schematic model showing a Late Carboniferous subduction and active continental margin; b Permian post-orogenic dextral shearing, uplifted asthenosphere and thinned lithosphere, where multi-originated magmatic rocks and pull-apart basin formed 



\section{Tables}

Table 1 A compilation of geochronological and geochemical data of Carboniferous to Permian igneous rocks in western Chinese Tianshan

\begin{tabular}{|c|c|c|c|c|c|c|c|}
\hline \multirow[b]{2}{*}{ Rocks } & \multirow[b]{2}{*}{ Localities } & \multicolumn{2}{|l|}{ Age } & \multicolumn{2}{|c|}{ Main geochemical } & \multirow[b]{2}{*}{ References } & \multirow[b]{2}{*}{ Type } \\
\hline & & Ma & Methods & $(\mathbf{L a} / \mathrm{Yb})$ & $\varepsilon \mathbf{N d}_{(T)}$ & & \\
\hline Andesite & Borohoro & $363.2 \pm 5.7$ & $\begin{array}{l}\text { Zircon U-Pb } \\
\text { SHRIMP }\end{array}$ & $4.9-12.6$ & & $\begin{array}{l}\text { Zhai et al. (2006) and Wang et al. } \\
(2007 a)\end{array}$ & $\mathrm{CA}$ \\
\hline Basalt & Nalati & $353.7 \pm 4.5$ & $\begin{array}{l}\text { Zircon U-Pb } \\
\text { SHRIMP }\end{array}$ & $4.1-5.8$ & $\begin{array}{l}+0.3 \text { to } \\
+3.1\end{array}$ & Zhu et al. (2006a) & $\mathrm{CA}$ \\
\hline Granodiorite & $\begin{array}{l}\text { W } \\
\text { Borohoro }\end{array}$ & $352 \pm 2$ & Zircon U-Pb TIMS & 3.02 & & Xu et al. (2006) & $\mathrm{CA}$ \\
\hline Granodiorite & Wusun & $348 \pm 1$ & Zircon U-Pb TIMS & 2.21 & & Xu et al. (2006) & $\mathrm{CA}$ \\
\hline Trachyte andesite & Nalati & $312.8 \pm 4.2$ & $\begin{array}{l}\text { Zircon U-Pb } \\
\text { SHRIMP }\end{array}$ & $3.5-5.9$ & $\begin{array}{l}+2.7 \text { to } \\
+4.9\end{array}$ & $\begin{array}{l}\text { Zhu et al. (2005) and Guo and Zhu } \\
\text { (2006) }\end{array}$ & $\mathrm{CA}$ \\
\hline Granodorite & Nalati & $308 \pm 1$ & Zircon U-Pb TIMS & 0.89 & & Xu et al. (2006) & $\mathrm{CA}$ \\
\hline Granodiorite & E Alataw & $307 \pm 3$ & Ar/Ar plateau & $2.2-4.5$ & $\begin{array}{l}+0.1 \text { to } \\
+6.9\end{array}$ & Chen et al. $(1994,2000)$ & $\mathrm{CA}$ \\
\hline Porphyritic granite & N Alataw & $298.4 \pm 5.7$ & Zircon U-Pb & $3.15-5.96$ & $\begin{array}{l}+3.5 \text { to } \\
+3.6\end{array}$ & Liu et al. (2005) & $\mathrm{CA}$ \\
\hline Diorite & S Tianshan & 298 & Zircon U-Pb & 34 & -6.5 & Jiang et al. (1999) & A \\
\hline $\begin{array}{l}\text { Biotite granite } \\
(\mathrm{B} 101)\end{array}$ & Borohoro & $294 \pm 7$ & Zircon $\mathrm{U}-\mathrm{Pb}$ & 7.2 & & This study & TR \\
\hline K-granite & S Alataw & $292.4 \pm 4.9$ & Zircon U-Pb & $2.75-3.5$ & +5 & Liu et al. (2005) & $\mathrm{CA}$ \\
\hline K-granite & W Alataw & $290 \pm 5$ & Ar/Ar plateau & $2.6-6.2$ & $\begin{array}{l}+0.9 \text { to } \\
+3.2\end{array}$ & Liu et al. (2005) & TR \\
\hline Diabase porphyre & Bogda & $288.9 \pm 4.7$ & Zircon U-Pb & $4.5-5.9$ & & Shu et al. (2005) & A \\
\hline
\end{tabular}




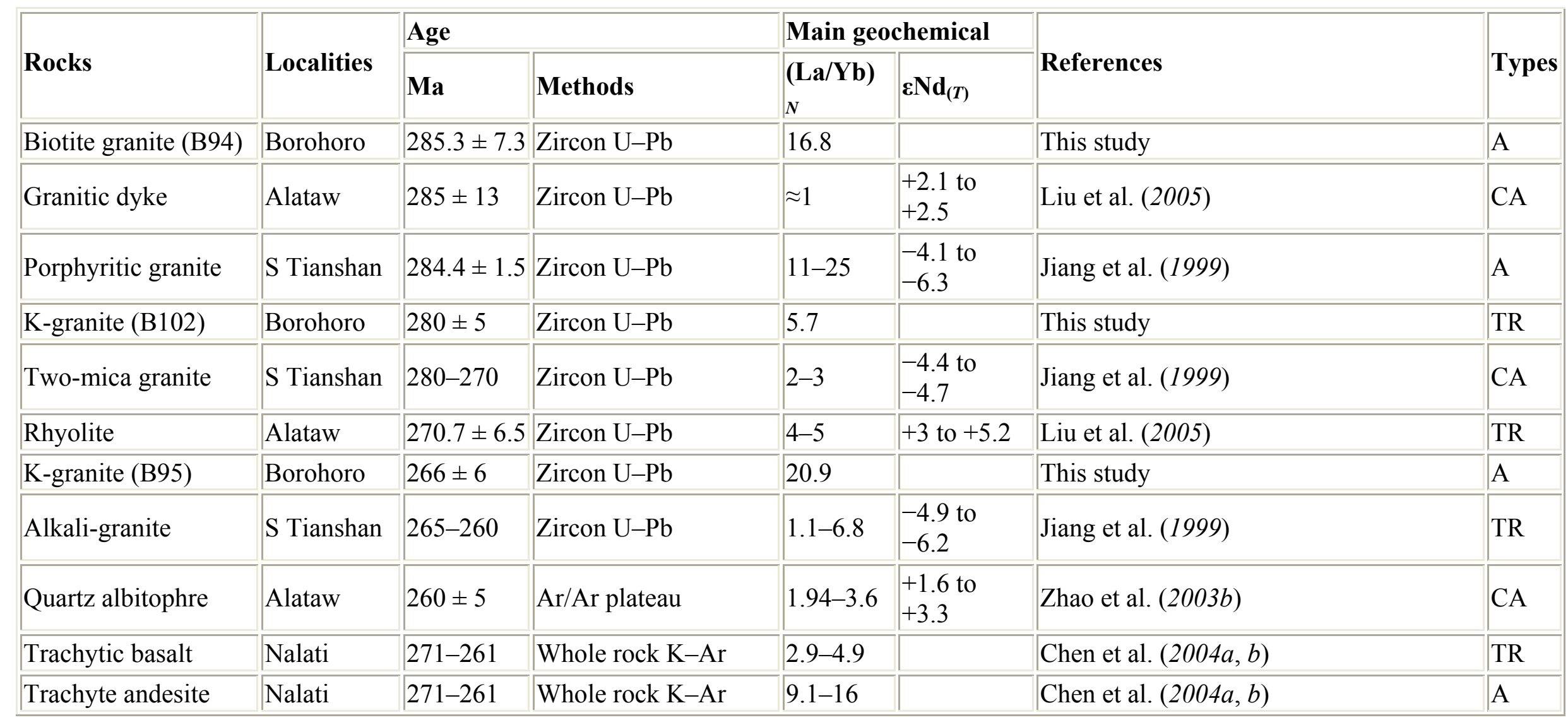

$C A$ Calc-alkaline series, $A$ alkaline series, $T R$ transitional series 
Table 2 Zircon U-Pb LA-ICPMS analysis results of the granitoids from the western Chinese Tianshan

\begin{tabular}{|c|c|c|c|c|c|c|c|c|c|c|c|c|c|c|c|c|c|}
\hline \multirow{2}{*}{ No } & \multicolumn{3}{|c|}{ Compositions } & \multirow{2}{*}{\begin{tabular}{|l} 
Atomic ratios \\
${ }^{207} \mathrm{~Pb} /{ }^{235} \mathrm{U}$ \\
\end{tabular}} & \multirow{2}{*}{\begin{tabular}{|l|}
$\sigma$ \\
\end{tabular}} & \multirow[b]{2}{*}{${ }^{206} \mathrm{~Pb} /{ }^{238} \mathrm{U}$} & \multirow[b]{2}{*}{$1 \sigma$} & \multirow[b]{2}{*}{${ }^{207} \mathrm{~Pb} /{ }^{206} \mathrm{~Pb}$} & \multirow[b]{2}{*}{$1 \sigma$} & \multirow[b]{2}{*}{${ }^{207} \mathrm{~Pb} /{ }^{235} \mathrm{U}$} & \multirow[b]{2}{*}{$1 \sigma$} & \multirow[b]{2}{*}{${ }^{206} \mathrm{~Pb} /{ }^{238} \mathrm{U}$} & \multirow[b]{2}{*}{$1 \sigma$} & \multirow[b]{2}{*}{${ }^{207} \mathrm{~Pb} /{ }^{206} \mathrm{~Pb}$} & \multicolumn{2}{|c|}{ Apparent ages (Ma) } & \multirow{2}{*}{ Disc (\%) } \\
\hline & Th ( ppm) & $\mathbf{U}(\mathbf{p p m})$ & $\mathbf{T h} / \mathbf{U}$ & & & & & & & & & & & & $1 \sigma$ & & \\
\hline \multicolumn{17}{|c|}{ Borohoro granodiorite B94 (GPS:N4350.30', E83³1.55') } & \\
\hline 1 & 262 & 424 & 0.62 & 0.32 & 0.06 & 0.039 & 0.0020 & 0.068 & 0.012 & 283 & 44 & 249 & 13 & 880 & 367 & 13 & \\
\hline 2 & 138 & 232 & 0.60 & 0.30 & 0.02 & 0.043 & 0.0006 & 0.053 & 0.003 & 266 & 14 & 268 & 4 & 317 & 136 & 4 & \\
\hline 3 & 207 & 402 & 0.52 & 0.31 & 0.02 & 0.043 & 0.0006 & 0.054 & 0.003 & 274 & 12 & 270 & 4 & 389 & 113 & 4 & \\
\hline 4 & 120 & 320 & 0.38 & 0.27 & 0.02 & 0.043 & 0.0007 & 0.049 & 0.004 & 247 & 14 & 268 & 4 & 156 & 175 & 4 & \\
\hline 5 & 73 & 163 & 0.45 & 0.30 & 0.02 & 0.044 & 0.0006 & 0.050 & 0.003 & 263 & 15 & 275 & 4 & 195 & 154 & 4 & \\
\hline 6 & 72 & 150 & 0.48 & 0.33 & 0.02 & 0.045 & 0.0008 & 0.056 & 0.005 & 286 & 19 & 282 & 5 & 453 & 182 & 5 & \\
\hline 7 & 62 & 126 & 0.49 & 0.33 & 0.03 & 0.047 & 0.0009 & 0.056 & 0.005 & 292 & 22 & 298 & 6 & 449 & 207 & 6 & \\
\hline 8 & 2,671 & 5,013 & 0.53 & 0.30 & 0.01 & 0.044 & 0.0003 & 0.051 & 0.001 & 270 & 6 & 276 & 2 & 248 & 58 & 2 & \\
\hline 9 & 1,504 & 3,339 & 0.45 & 0.32 & 0.01 & 0.046 & 0.0003 & 0.052 & 0.001 & 283 & 5 & 291 & 2 & 280 & 51 & 2 & \\
\hline 10 & 2,480 & 5,844 & 0.42 & 0.32 & 0.01 & 0.046 & 0.0004 & 0.052 & 0.001 & 284 & 5 & 293 & 2 & 267 & 44 & 3 & \\
\hline 11 & 3,498 & 6,418 & 0.55 & 0.33 & 0.01 & 0.047 & 0.0004 & 0.053 & 0.001 & 293 & 5 & 296 & 2 & 323 & 44 & 2 & \\
\hline 12 & 3,035 & 5,215 & 0.58 & 0.35 & 0.01 & 0.047 & 0.0007 & 0.055 & 0.002 & 303 & 11 & 297 & 4 & 419 & 97 & 4 & \\
\hline \multicolumn{17}{|c|}{ Borohoro K-granite B95 (GPS:N4350.30', E83³1.55') } & \\
\hline 1 & 138 & 137 & 1.01 & 2.82 & 0.16 & 0.057 & 0.0017 & 0.352 & 0.014 & 1,361 & 45 & 356 & 10 & 3,714 & 62 & 10 & \\
\hline 2 & 79 & 178 & 0.45 & 0.33 & 0.02 & 0.040 & 0.0007 & 0.063 & 0.004 & 293 & 15 & 250 & 4 & 695 & 127 & 4 & \\
\hline 3 & 3,098 & 5,976 & 0.52 & 0.46 & 0.01 & 0.042 & 0.0003 & 0.080 & 0.002 & 387 & 6 & 266 & 2 & 1,186 & 37 & 2 & \\
\hline 4 & 1,691 & 3,324 & 0.51 & 0.43 & 0.01 & 0.042 & 0.0005 & 0.076 & 0.003 & 365 & 11 & 266 & 3 & 1,087 & 67 & 3 & \\
\hline 5 & 97 & 182 & 0.53 & 0.34 & 0.02 & 0.042 & 0.0006 & 0.061 & 0.004 & 296 & 17 & 264 & 4 & 634 & 153 & 4 & \\
\hline 6 & 124 & 279 & 0.44 & 0.34 & 0.02 & 0.042 & 0.0006 & 0.058 & 0.004 & 296 & 17 & 264 & 3 & 522 & 138 & 4 & \\
\hline 7 & 1,270 & 2,716 & 0.47 & 0.31 & 0.01 & 0.042 & 0.0003 & 0.054 & 0.001 & 274 & 6 & 266 & 2 & 354 & 52 & 2 & \\
\hline 8 & 118 & 181 & 0.65 & 0.31 & 0.03 & 0.042 & 0.0013 & 0.058 & 0.007 & 277 & 26 & 267 & 8 & 514 & 252 & 8 & \\
\hline 9 & 698 & 1,998 & 0.35 & 0.35 & 0.01 & 0.043 & 0.0004 & 0.060 & 0.002 & 308 & 7 & 271 & 3 & 621 & 67 & 3 & \\
\hline 10 & 8,271 & 10,479 & 0.79 & 0.32 & 0.01 & 0.043 & 0.0002 & 0.054 & 0.001 & 282 & 5 & 270 & 2 & 381 & 42 & 2 & \\
\hline
\end{tabular}




\begin{tabular}{|c|c|c|c|c|c|c|c|c|c|c|c|c|c|c|c|c|c|}
\hline \multirow{2}{*}{ No } & \multicolumn{3}{|c|}{ Compositions } & \multirow{2}{*}{\begin{tabular}{|l} 
Atomic ratios \\
${ }^{207} \mathrm{~Pb} /{ }^{235} \mathrm{U}$
\end{tabular}} & \multirow{2}{*}{$1 \sigma$} & \multirow[b]{2}{*}{${ }^{206} \mathrm{~Pb} /{ }^{238} \mathrm{U}$} & \multirow[b]{2}{*}{$1 \sigma$} & \multirow[b]{2}{*}{${ }^{207} \mathrm{~Pb} /{ }^{206} \mathrm{~Pb}$} & \multirow[b]{2}{*}{$1 \sigma$} & \multirow[b]{2}{*}{${ }^{207} \mathrm{~Pb} /{ }^{235} \mathrm{U}$} & \multirow[b]{2}{*}{$1 \sigma$} & \multirow[b]{2}{*}{${ }^{206} \mathrm{~Pb} /{ }^{238} \mathrm{U}$} & \multirow[b]{2}{*}{$1 \sigma$} & \multirow[b]{2}{*}{${ }^{207} \mathrm{~Pb} /{ }^{206} \mathrm{~Pb}$} & \multicolumn{2}{|c|}{ Apparent ages (Ma) } & \multirow{2}{*}{$\operatorname{Disc}(\%)$} \\
\hline & Th ( ppm) & U (ppm) & $\mathbf{T h} / \mathbf{U}$ & & & & & & & & & & & & $1 \sigma$ & & \\
\hline 11 & 1,445 & 3,798 & 0.38 & 0.32 & 0.01 & 0.044 & 0.0003 & 0.053 & 0.001 & 281 & 5 & 277 & 2 & 331 & 50 & 2 & \\
\hline 12 & 203 & 527 & 0.38 & 0.39 & 0.01 & 0.054 & 0.0005 & 0.052 & 0.002 & 331 & $11 \mid$ & 339 & 3 & 276 & 95 & 3 & \\
\hline \multicolumn{17}{|c|}{ Borohoro granodiorite B101 (GPS:N4341.34', E84²4.86') } & \\
\hline 1 & 99 & 231 & 0.43 & 0.26 & 0.02 & 0.043 & 0.001 & 0.044 & 0.004 & 234 & 17 & 274 & 6 & -86 & 218 & 6 & \\
\hline 2 & 317 & 717 & 0.44 & 0.40 & 0.02 & 0.046 & 0.001 & 0.061 & 0.003 & 343 & 16 & 289 & 4 & 644 & 118 & 4 & \\
\hline 3 & 184 & 349 & 0.53 & 0.36 & 0.02 & 0.046 & 0.001 & 0.056 & 0.004 & 308 & 19 & 289 & 5 & 451 & 171 & 6 & \\
\hline 4 & 140 & 270 & 0.52 & 0.37 & 0.03 & 0.046 & 0.001 & 0.059 & 0.004 & 323 & 20 & 290 & 6 & 575 & 164 & 6 & \\
\hline 5 & 156 & 562 & 0.28 & 0.34 & 0.02 & 0.046 & 0.001 & 0.054 & 0.004 & 294 & 18 & 289 & 5 & 363 & 165 & 5 & \\
\hline 6 & 60 & 112 & 0.54 & 0.34 & 0.04 & 0.047 & 0.001 & 0.054 & 0.007 & 296 & 30 & 298 & 9 & 388 & 289 & 9 & \\
\hline 7 & 208 & 467 & 0.45 & 0.35 & 0.02 & 0.048 & 0.001 & 0.052 & 0.003 & 307 & 15 & 301 & 5 & 274 & 136 & 5 & \\
\hline 8 & 319 & 1,070 & 0.30 & 0.37 & 0.01 & 0.048 & 0.001 & 0.055 & 0.002 & 322 & $11 \mid$ & 303 & 3 & 416 & 91 & 3 & \\
\hline 9 & 332 & 1,567 & 0.21 & 0.61 & 0.02 & 0.050 & 0.001 & 0.086 & 0.003 & 486 & 13 & 317 & 5 & 1,336 & 67 & 5 & \\
\hline 10 & 169 & 347 & 0.49 & 0.38 & 0.02 & 0.049 & 0.001 & 0.055 & 0.004 & 326 & 18 & 311 & 5 & 392 & 149 & 5 & \\
\hline 11 & 284 & 564 & 0.50 & 0.38 & 0.02 & 0.050 & 0.001 & 0.054 & 0.003 & 325 & 16 & 315 & 5 & 376 & 137 & 5 & \\
\hline 12 & 390 & 1,111 & 0.35 & 0.81 & 0.03 & 0.096 & 0.001 & 0.060 & 0.002 & 605 & 16 & 590 & 7 & 594 & 80 & 7 & \\
\hline \multicolumn{17}{|c|}{ Borohoro K-granite B102 (GPS: N4346.10’, E84²6.2') } & \\
\hline 1 & 57 & 94 & 0.60 & 0.61 & 0.04 & 0.044 & 0.001 & 0.112 & 0.008 & 483 & $27 \mid$ & 279 & 6 & 1,827 & 129 & 6 & \\
\hline 2 & 36 & 89 & 0.41 & 0.28 & 0.02 & 0.043 & 0.001 & 0.054 & 0.005 & 249 & 20 & 270 & 6 & 377 & 210 & 6 & \\
\hline 3 & 42 & 81 & 0.52 & 0.35 & 0.03 & 0.044 & 0.001 & 0.065 & 0.006 & 302 & 24 & 278 & 6 & 786 & 188 & 6 & \\
\hline 4 & 54 & 95 & 0.57 & 0.27 & 0.03 & 0.044 & 0.001 & 0.049 & 0.005 & 245 & 23 & 275 & 6 & 166 & 245 & 6 & \\
\hline 5 & 38 & 72 & 0.53 & 0.33 & 0.04 & 0.045 & 0.001 & 0.062 & 0.007 & 292 & $28 \mid$ & 281 & 7 & 659 & 231 & 8 & \\
\hline 6 & 50 & 87 & 0.58 & 0.25 & 0.03 & 0.044 & 0.001 & 0.052 & 0.006 & 223 & 25 & 279 & 6 & 307 & 275 & 6 & \\
\hline 7 & 44 & 72 & 0.61 & 0.28 & 0.03 & 0.045 & 0.001 & 0.052 & 0.006 & 249 & 26 & 281 & 7 & 272 & 275 & 7 & \\
\hline 8 & 64 & 92 & 0.70 & 0.24 & 0.03 & 0.044 & 0.001 & 0.043 & 0.006 & 220 & $27 \mid$ & 280 & 7 & -153 & 342 & 7 & \\
\hline 9 & 90 & 128 & 0.70 & 0.30 & 0.03 & 0.045 & 0.001 & 0.054 & 0.005 & 263 & 23 & 284 & 6 & 366 & 220 & 6 & \\
\hline 10 & 31 & 67 & 0.47 & 0.30 & 0.04 & 0.045 & 0.001 & 0.052 & 0.007 & 267 & 29 & 285 & 7 & 305 & 295 & 7 & \\
\hline
\end{tabular}




\begin{tabular}{|c|c|c|c|c|c|c|c|c|c|c|c|c|c|c|c|c|c|}
\hline \multirow{2}{*}{ No } & \multicolumn{3}{|c|}{ Compositions } & \multirow{2}{*}{$\begin{array}{l}\text { Atomic ratios } \\
{ }^{207} \mathrm{~Pb} /{ }^{235} \mathrm{U}\end{array}$} & \multirow{2}{*}{$1 \sigma$} & \multirow[b]{2}{*}{${ }^{206} \mathrm{~Pb} /{ }^{238} \mathrm{U}$} & \multirow[b]{2}{*}{$1 \sigma$} & \multirow[b]{2}{*}{${ }^{207} \mathrm{~Pb} /{ }^{206} \mathrm{~Pb}$} & \multirow[b]{2}{*}{$1 \sigma$} & \multirow[b]{2}{*}{${ }^{207} \mathrm{~Pb} /{ }^{235} \mathrm{U}$} & \multirow[b]{2}{*}{$1 \sigma$} & \multirow[b]{2}{*}{${ }^{206} \mathrm{~Pb} /{ }^{238} \mathrm{U}$} & \multirow[b]{2}{*}{$1 \sigma$} & \multirow[b]{2}{*}{${ }^{207} \mathrm{~Pb} /{ }^{206} \mathrm{~Pb}$} & \multicolumn{2}{|c|}{ Apparent ages (Ma) } & \multirow{2}{*}{$\operatorname{Disc}(\%)$} \\
\hline & Th ( ppm) & $\mathbf{U}(\mathbf{p p m})$ & $\mathbf{T h} / \mathbf{U}$ & & & & & & & & & & & & $1 \sigma$ & & \\
\hline 11 & 58 & 95 & 0.61 & 0.34 & 0.04 & 0.046 & 0.001 & 0.061 & 0.007 & 294 & 28 & 292 & 6 & 647 & 236 & 7 & \\
\hline 12 & 29 & 66 & 0.44 & 0.39 & 0.04 & 0.048 & 0.001 & 0.068 & 0.006 & 335 & 26 & 301 & 7 & 857 & 194 & 8 & \\
\hline \multicolumn{17}{|c|}{ Kekesu K-granite KKS5 (GPS: N4245.98’, E8155.44’) } & \\
\hline 1 & 1,694 & 3,255 & 0.52 & 0.32 & 0.01 & 0.037 & 0.0003 & 0.065 & 0.002 & 279 & 6 & 235 & 2 & 778 & 50 & 2 & \\
\hline 2 & 1,131 & 889 & 1.27 & 0.54 & 0.02 & 0.044 & 0.0005 & 0.093 & 0.003 & 441 & 13 & 280 & 3 & 1,487 & 68 & 3 & \\
\hline 3 & 333 & 809 & 0.41 & 0.36 & 0.01 & 0.044 & 0.0004 & 0.062 & 0.003 & 311 & 10 & 278 & 2 & 674 & 87 & 3 & \\
\hline 4 & 1,754 & 998 & 1.76 & 0.31 & 0.01 & 0.044 & 0.0004 & 0.053 & 0.002 & 271 & 9 & 275 & 2 & 341 & 83 & 2 & \\
\hline 5 & 536 & 718 & 0.75 & 0.46 & 0.03 & 0.045 & 0.0011 & 0.080 & 0.006 & 383 & 25 & 286 & 7 & 1,209 & 145 & 7 & \\
\hline 6 & 746 & 691 & 1.08 & 0.43 & 0.02 & 0.045 & 0.0006 & 0.072 & 0.003 & 361 & 15 & 285 & 4 & 977 & 99 & 4 & \\
\hline 7 & 752 & 832 & 0.90 & 0.33 & 0.01 & 0.044 & 0.0004 & 0.056 & 0.002 & 290 & 11 & 280 & 3 & 468 & 94 & 3 & \\
\hline 8 & 616 & 1,464 & 0.42 & 0.36 & 0.01 & 0.045 & 0.0004 & 0.061 & 0.002 & 311 & 7 & 283 & 2 & 649 & 56 & 2 & \\
\hline 9 & 458 & 758 & 0.60 & 0.45 & 0.02 & 0.046 & 0.0005 & 0.074 & 0.004 & 378 & 15 & 288 & 3 & 1,048 & 95 & 3 & \\
\hline 10 & 503 & 434 & 1.16 & 0.37 & 0.03 & 0.050 & 0.0011 & 0.059 & 0.004 & 323 & 20 & 315 & 7 & 558 & 152 & 7 & \\
\hline 11 & 182 & 648 & 0.28 & 0.42 & 0.02 & 0.060 & 0.0006 & 0.054 & 0.002 & 358 & 11 & 375 & 4 & 372 & 81 & 4 & \\
\hline 12 & 746 & 501 & 1.49 & 3.49 & 0.33 & 0.074 & 0.0034 & 0.362 & 0.022 & 1,526 & 76 & 458 & 20 & 3,760 & 92 & 19 & \\
\hline \multicolumn{17}{|c|}{ 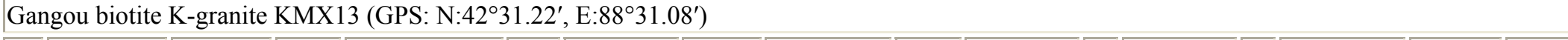 } & \\
\hline 1 & 837 & 627 & 1.34 & 0.27 & 0.01 & 0.039 & 0.001 & 0.052 & 0.002 & 244 & 10 & 248 & 3 & 306 & 100 & 3 & \\
\hline 2 & 242 & 240 & 1.01 & 0.30 & 0.02 & 0.040 & 0.001 & 0.056 & 0.004 & 264 & 15 & 251 & 4 & 458 & 141 & 4 & \\
\hline 3 & 658 & 698 & 0.94 & 0.32 & 0.02 & 0.040 & 0.001 & 0.061 & 0.003 & 282 & 13 & 254 & 5 & 654 & 119 & 5 & \\
\hline 4 & 277 & 577 & 0.48 & 0.32 & 0.02 & 0.040 & 0.001 & 0.063 & 0.004 & 284 & 16 & 255 & 5 & 709 & 128 & 5 & \\
\hline 5 & 617 & 451 & 1.37 & 0.32 & 0.01 & 0.041 & 0.001 & 0.060 & 0.003 & 281 & 11 & 258 & 4 & 603 & 97 & 5 & \\
\hline 6 & 120 & 227 & 0.53 & 0.30 & 0.03 & 0.041 & 0.001 & 0.057 & 0.006 & 267 & 25 & 258 & 6 & 499 & 233 & 6 & \\
\hline 7 & 58 & 122 & 0.48 & 0.29 & 0.04 & 0.041 & 0.001 & 0.054 & 0.007 & 261 & 32 & 259 & 8 & 361 & 314 & 8 & \\
\hline 8 & 370 & 317 & 1.17 & 0.33 & 0.03 & 0.042 & 0.001 & 0.061 & 0.005 & 287 & 21 & 262 & 7 & 656 & 173 & 7 & \\
\hline 9 & 123 & 214 & 0.58 & 0.33 & 0.03 & 0.049 & 0.001 & 0.050 & 0.005 & 288 & 23 & 311 & 6 & 204 & 217 & 6 & \\
\hline 10 & 207 & 325 & 0.63 & 0.36 & 0.02 & 0.054 & 0.001 & 0.051 & 0.003 & 314 & 17 & 337 & 6 & 259 & 149 & 6 & \\
\hline
\end{tabular}




\begin{tabular}{|c|c|c|c|c|c|c|c|c|c|c|c|c|c|c|c|c|c|}
\hline \multirow{2}{*}{ No } & \multicolumn{3}{|c|}{ Compositions } & \multirow{2}{*}{\begin{tabular}{|l} 
Atomic ratios \\
${ }^{207} \mathrm{~Pb} /{ }^{235} \mathrm{U}$
\end{tabular}} & \multirow{2}{*}{$1 \sigma$} & \multirow[b]{2}{*}{${ }^{206} \mathrm{~Pb} /{ }^{238} \mathrm{U}$} & \multirow[b]{2}{*}{$1 \sigma$} & \multirow[b]{2}{*}{${ }^{207} \mathrm{~Pb} /{ }^{206} \mathrm{~Pb}$} & \multirow[b]{2}{*}{$1 \sigma$} & \multirow[b]{2}{*}{${ }^{207} \mathrm{~Pb} /{ }^{235} \mathrm{U}$} & \multirow[b]{2}{*}{$1 \sigma$} & \multirow[b]{2}{*}{${ }^{206} \mathrm{~Pb} /{ }^{238} \mathrm{U}$} & \multirow[b]{2}{*}{$1 \sigma$} & \multirow[b]{2}{*}{${ }^{207} \mathrm{~Pb} /{ }^{206} \mathrm{~Pb}$} & \multicolumn{2}{|c|}{ Apparent ages (Ma) } & \multirow{2}{*}{ Disc (\%) } \\
\hline & Th ( ppm) & $\mathbf{U}$ (ppm) & $\mathbf{T h} / \mathbf{U}$ & & & & & & & & & & & & $1 \sigma$ & & \\
\hline 11 & 852 & 874 & 0.98 & 0.40 & 0.02 & 0.057 & 0.001 & 0.053 & 0.002 & 338 & 12 & 356 & 6 & 317 & 90 & 6 & \\
\hline 12 & 757 & 554 & 1.37 & 0.43 & 0.02 & 0.057 & 0.001 & 0.057 & 0.003 & 362 & 17 & 358 & 7 & 474 & 121 & 7 & \\
\hline
\end{tabular}

Table 3 A synthesis of Whole rock geochemistry of Permian magmatic rocks in Borohoro, Alataw, Southern Tianshan, Nalati and Bogda areas,

West Chinese Tianshan

\begin{tabular}{|c|c|c|c|c|c|c|c|c|c|c|c|c|}
\hline \multirow{2}{*}{\begin{tabular}{|l|} 
Locations \\
$\begin{array}{l}\text { Sample } \\
\text { no. }\end{array}$ \\
\end{tabular}} & \multicolumn{4}{|l|}{ Borohoro } & \multicolumn{4}{|l|}{ Alataw } & \multicolumn{4}{|c|}{ Nalati (Aikendaban Fm.) } \\
\hline & B94 & B95 & B101 & B102 & kwsy12 & kwsy3 & kwsy27 & kwsy17 & a1-39 & a1-45 & a1-38 & a1-4 \\
\hline Age & $285 \mathrm{Ma}$ & $266 \mathrm{Ma}$ & 294 Мa & $280 \mathrm{Ma}$ & $298 \mathrm{Ma}$ & $285 \mathrm{Ma}$ & 292 Ma & $271 \mathrm{Ma}$ & $\mathbf{P 2}$ & $\mathbf{P 1}$ & P1 & $\mathbf{P 1}$ \\
\hline Rocks & Granodiorite & \begin{tabular}{|l} 
K- \\
granite
\end{tabular} & Granodiorite & \begin{tabular}{|l|} 
K- \\
granite
\end{tabular} & Granite & $\begin{array}{l}\text { Granitic } \\
\text { dyke }\end{array}$ & Granite & Rhyolite & $\begin{array}{l}\text { Shoshonite } \\
\text { (?) }\end{array}$ & $\begin{array}{l}\text { Trachyte } \\
\text { andesite }\end{array}$ & $\begin{array}{l}\text { Trachytic } \\
\text { andesite }\end{array}$ & Trachyte \\
\hline References & \multicolumn{4}{|l|}{ This study } & \multicolumn{4}{|c|}{ Liu et al. (2006) } & \multicolumn{4}{|c|}{ Chen et al. $(2004 a, b)$} \\
\hline $\mathrm{SiO}_{2}$ & 71.4 & 71.35 & 72.79 & 69.39 & 73.05 & 76.97 & 77.16 & 74.45 & 41.69 & 53.46 & 54.79 & 59.99 \\
\hline $\mathrm{TiO}_{2}$ & 0.23 & 0.22 & 0.24 & 0.47 & 0.29 & 0.08 & 0.1 & 0.25 & 0.91 & 1.31 & 1.19 & 0.94 \\
\hline $\mathrm{Al}_{2} \mathrm{O}_{3}$ & 14.01 & 13.78 & 14.06 & 13.93 & 13.39 & 12.43 & 12.36 & 11.95 & 18.29 & 15.2 & 17.23 & 15.63 \\
\hline $\mathrm{Fe}_{2} \mathrm{O}_{3}$ & 2.66 & 2.54 & 1.77 & 3.9 & 2.43 & 0.93 & 1.38 & 2.28 & 4.14 & 3.13 & 3.31 & 2.6 \\
\hline $\mathrm{MnO}$ & 0.05 & 0.06 & 0.05 & 0.08 & 0.05 & 0.01 & 0.02 & 0.04 & 0.23 & 0.16 & 0.13 & 0.15 \\
\hline $\mathrm{MgO}$ & 0.1 & 0.09 & 0.51 & 0.49 & 0.52 & 0.04 & 0.03 & 0.14 & 4.78 & 7.46 & 3.92 & 3.37 \\
\hline $\mathrm{CaO}$ & 0.88 & 0.8 & 2.09 & 2.03 & 1.65 & 0.44 & 0.44 & 1.31 & 20.43 & 5.01 & 5.31 & 0.76 \\
\hline $\mathrm{Na}_{2} \mathrm{O}$ & 3.9 & 3.78 & 3.72 & 4.02 & 3.7 & 3.91 & 3.85 & 3.35 & 0.33 & 4.75 & 4.22 & 4.1 \\
\hline $\mathrm{K}_{2} \mathrm{O}$ & 5.75 & 5.65 & 3.3 & 3.72 & 4.37 & 4.57 & 4.8 & 3.93 & 0.11 & 1.75 & 4.26 & 5.72 \\
\hline
\end{tabular}




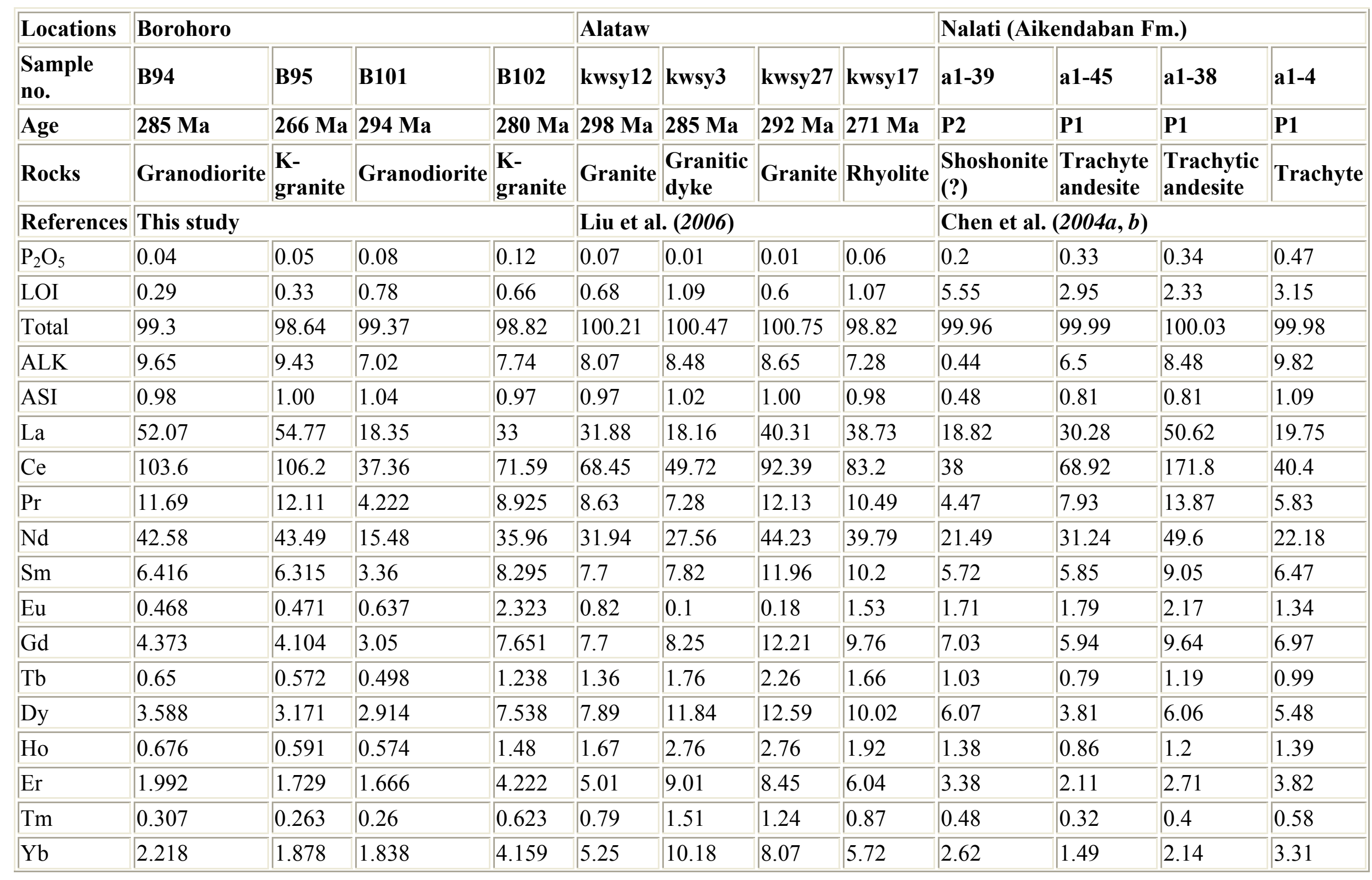




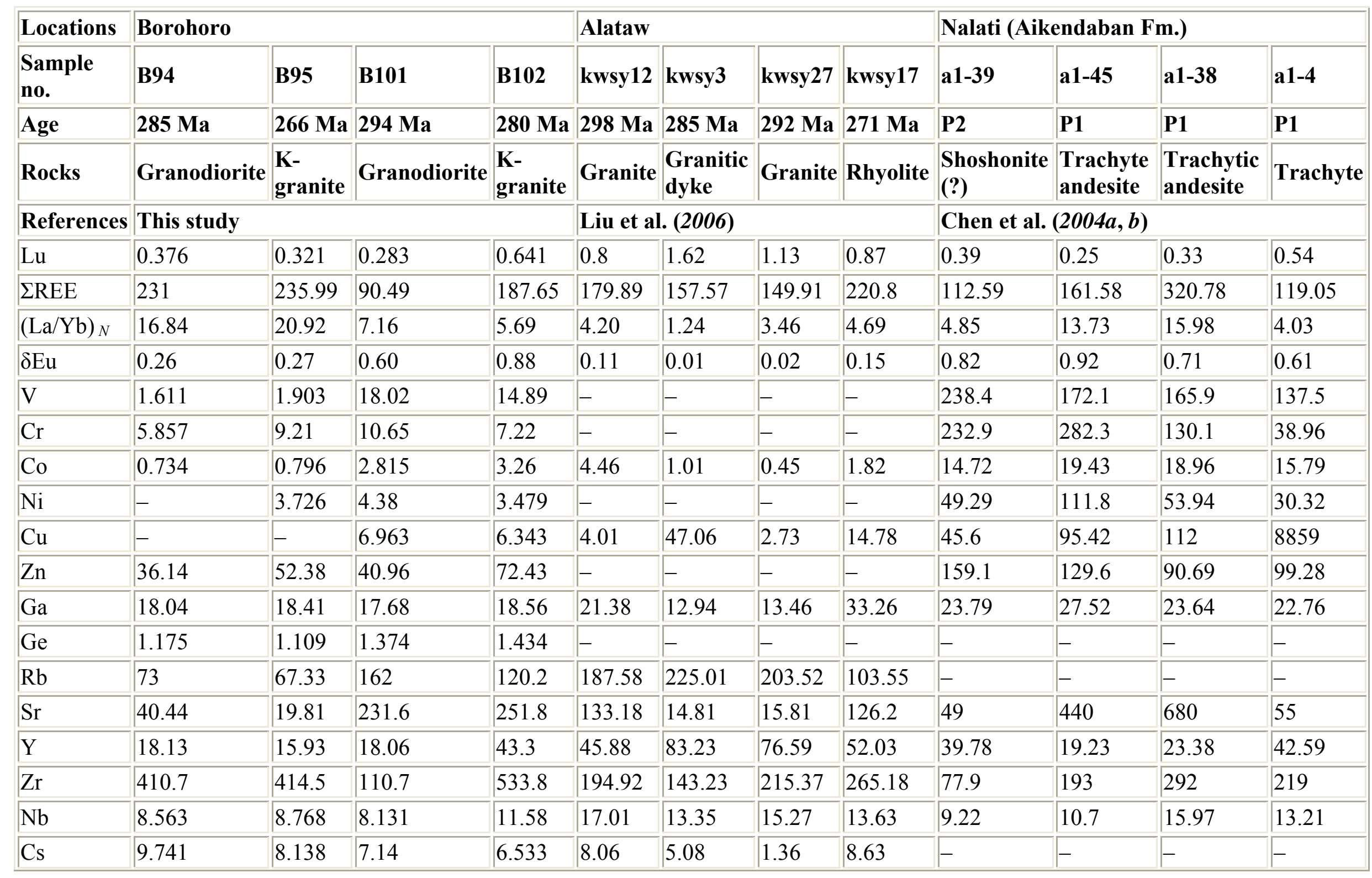




\begin{tabular}{|c|c|c|c|c|c|c|c|c|c|c|c|c|c|}
\hline \multirow{2}{*}{\begin{tabular}{|l|} 
Locations \\
Sample \\
no.
\end{tabular}} & \multicolumn{4}{|l|}{ Borohoro } & \multicolumn{5}{|l|}{ Alataw } & \multicolumn{4}{|c|}{ Nalati (Aikendaban Fm.) } \\
\hline & B94 & B95 & B101 & B102 & kwsy12 & kwsy3 & kwsy27 & \multicolumn{2}{|c|}{ kwsy17 } & a1-39 & a1-45 & a1-38 & a1-4 \\
\hline Age & $285 \mathrm{Ma}$ & $266 \mathrm{Ma}$ & $294 \mathrm{Ma}$ & $280 \mathrm{Ma}$ & $298 \mathrm{Ma}$ & $285 \mathrm{Ma}$ & $292 \mathrm{Ma}$ & \multicolumn{2}{|c|}{$271 \mathrm{Ma}$} & $\mathbf{P 2}$ & P1 & P1 & P1 \\
\hline Rocks & Granodiorite & $\begin{array}{l}\text { K- } \\
\text { granite }\end{array}$ & Granodiorit & ite $\begin{array}{l}\text { K- } \\
\text { granite }\end{array}$ & Granite & $\begin{array}{l}\text { Granitic } \\
\text { dyke }\end{array}$ & Granite & \multicolumn{2}{|c|}{ Rhyolite } & $\begin{array}{l}\text { Shoshonite } \\
\text { (?) }\end{array}$ & $\begin{array}{l}\text { ite } \begin{array}{l}\text { Trachyte } \\
\text { andesite }\end{array} \\
\end{array}$ & $\begin{array}{l}\text { Trachytic } \\
\text { andesite }\end{array}$ & Trachyte \\
\hline References & \multicolumn{4}{|l|}{ This study } & \multicolumn{5}{|c|}{ Liu et al. (2006) } & \multicolumn{4}{|c|}{ Chen et al. $(2004 a, b)$} \\
\hline $\mathrm{Ba}$ & 134.3 & 124.6 & 330.3 & 1152 & 407.87 & 47.96 & 60.26 & \multicolumn{2}{|c|}{881.47} & 76 & 312 & 826 & 934 \\
\hline Hf & 9.486 & 9.55 & 3.21 & 10.56 & 7.02 & 7.64 & 9.22 & \multicolumn{2}{|c|}{8.59} & 2.12 & 3.25 & 6.19 & 6.03 \\
\hline $\mathrm{Ta}$ & 0.854 & 0.608 & 1.447 & 1.206 & 3.93 & 2.02 & 1.44 & \multicolumn{2}{|c|}{0.87} & 0.7 & 0.36 & 1.32 & 0.62 \\
\hline $\mathrm{Th}$ & 7.68 & 7.499 & 12.19 & 11.54 & 19.82 & 42.71 & 21.92 & \multicolumn{2}{|c|}{12.22} & - & - & - & - \\
\hline $\mathrm{Pb}$ & 13.5221 & 15.539 & 22.251 & 19.322 & 19.58 & 18.07 & 22.18 & \multicolumn{2}{|c|}{18.7} & 25.14 & 25.97 & 25.7 & 27.77 \\
\hline $\mathrm{U}$ & 1.965 & 1.295 & 2.516 & 2.674 & 2.94 & 7.81 & 5.21 & \multicolumn{2}{|c|}{3.94} & - & - & - & - \\
\hline $\mathrm{Th} / \mathrm{Ta}$ & 8.99297 & 12.334 & 8.4243 & 9.5688 & 5.04326 & 21.1436 & 15.2222 & \multicolumn{2}{|c|}{14.04598} & - & - & - & - \\
\hline $\mathrm{Ce} / \mathrm{Pb}$ & 7.66 & 6.83 & 1.68 & 3.71 & 3.50 & 2.75 & 4.17 & \multicolumn{2}{|c|}{4.45} & 1.51 & 2.65 & 6.68 & 1.45 \\
\hline $\mathrm{Nb} / \mathrm{La}$ & 0.16 & 0.16 & 0.44 & 0.35 & 0.53 & 0.74 & 0.38 & \multicolumn{2}{|c|}{0.35} & 0.49 & 0.35 & 0.32 & 0.67 \\
\hline $\mathrm{Th} / \mathrm{La}$ & 0.15 & 0.14 & 0.66 & 0.35 & 0.62 & 2.35 & 0.54 & 0.32 & & - & - & - & - \\
\hline Locations & Southern Tian & nshan & & & & & & & Bogd & & & & \\
\hline Sample no. & 1 & 5 & & $16-6$ & & 29-12 & & & 2961 & 2962 & 302 & 2989 & \\
\hline Age & $298 \mathrm{Ma}$ & $284 \mathrm{Ma}$ & & $280-270 \mathrm{~N}$ & & $264 \mathrm{Ma}$ & & & P1 & P1 & $289 \mathrm{Ma}$ & P1 & \\
\hline Rocks & Granodiorite & Porphyı & ritic granite & Two-mica & granite & Alkali feld & dspar gra & anite & Basal & It Basalt & Dacite dyke & Rhyolite & \\
\hline References & Jiang et al. (1) & 999) & & & & & & & Shu e & et al. $(200$ & 5) & & \\
\hline $\mathrm{SiO}_{2}$ & 59.69 & 70.6 & & 74.3 & & 75.5 & & & 51.43 & 52.08 & 49.68 & 71.13 & \\
\hline $\mathrm{TiO}_{2}$ & 0.97 & 0.33 & & 0.3 & & 0.1 & & & 1.09 & 1.42 & 1.38 & 0.21 & \\
\hline
\end{tabular}




\begin{tabular}{|c|c|c|c|c|c|c|c|c|}
\hline \multirow{2}{*}{\begin{tabular}{|l} 
Locations \\
Sample no.
\end{tabular}} & \multicolumn{4}{|c|}{ Southern Tianshan } & \multicolumn{4}{|l|}{ Bogda } \\
\hline & 1 & 5 & $16-6$ & $29-12$ & 2961 & 2962 & 302 & 2989 \\
\hline Age & $298 \mathrm{Ma}$ & $284 \mathrm{Ma}$ & $280-270 \mathrm{Ma}$ & $264 \mathrm{Ma}$ & P1 & P1 & $289 \mathrm{Ma}$ & P1 \\
\hline Rocks & Granodiorite & Porphyritic granite & Two-mica granite & Alkali feldspar granite & Basalt & Basalt & Dacite dyke & Rhyolite \\
\hline References & \multicolumn{4}{|c|}{ Jiang et al. (1999) } & \multicolumn{4}{|c|}{ Shu et al. (2005) } \\
\hline $\mathrm{Al}_{2} \mathrm{O}_{3}$ & 16.44 & 13.91 & 14.4 & 12.27 & 15.37 & 14.76 & 15.25 & 12.48 \\
\hline $\mathrm{Fe}_{2} \mathrm{O}_{3}$ & 4.2 & 0.81 & 0.72 & 1.74 & 4.35 & 5.16 & 4.79 & 2.36 \\
\hline $\mathrm{MnO}$ & 0.04 & 0.05 & 0.01 & 0.06 & 0.13 & 0.16 & 0.18 & 0.09 \\
\hline $\mathrm{MgO}$ & 2.41 & 0.46 & 0.41 & 0.18 & 6.35 & 7.25 & 6.86 & 0.58 \\
\hline $\mathrm{CaO}$ & 4.71 & 1.52 & 0.99 & 0.3 & 8.52 & 8.58 & 8.46 & 1.13 \\
\hline $\mathrm{Na}_{2} \mathrm{O}$ & 4.74 & 3.7 & 4 & 3.86 & 2.86 & 2.36 & 2.62 & 3.52 \\
\hline $\mathrm{K}_{2} \mathrm{O}$ & 2.95 & 4.7 & 4.48 & 4.9 & 0.73 & 0.82 & 0.83 & 5.56 \\
\hline $\mathrm{P}_{2} \mathrm{O}_{5}$ & 0.47 & 0.13 & 0.05 & 0.06 & 0.23 & 0.18 & 0.24 & 0.08 \\
\hline LOI & 0.92 & 1.3 & 0.35 & 0.24 & 1.04 & 0.86 & 1.13 & 0.85 \\
\hline Total & 100.27 & 99.8 & 100.7 & 99.9 & 99.68 & 100.4 & 99.83 & 99.01 \\
\hline ALK & 7.69 & 8.4 & 8.48 & 8.76 & 3.59 & 3.18 & 3.45 & 9.08 \\
\hline ASI & 0.84 & 1.00 & 1.09 & 1.00 & 0.73 & 0.72 & 0.74 & 0.90 \\
\hline $\mathrm{La}$ & 81.57 & 68.39 & 5.74 & 22.5 & 24.79 & 24.43 & 18.55 & 34.32 \\
\hline $\mathrm{Ce}$ & 151.19 & 136.72 & 12.44 & 57.44 & 52.22 & 51.75 & 39.57 & 72.93 \\
\hline $\operatorname{Pr}$ & 17.16 & 15.41 & 1.22 & 7.28 & 7.66 & 6.89 & 5.62 & 11.69 \\
\hline $\mathrm{Nd}$ & 59 & 51.52 & 4.91 & 27.9 & 28.35 & 26.73 & 20.23 & 39.62 \\
\hline $\mathrm{Sm}$ & 9.98 & 102 & 1.74 & 7.97 & 5.66 & 6.32 & 4.85 & 11.75 \\
\hline $\mathrm{Eu}$ & 2.05 & 1.33 & 0.52 & 0.36 & 2.14 & 2.13 & 1.64 & 1.32 \\
\hline $\mathrm{Gd}$ & 5.71 & 8.52 & 1.41 & 6.54 & 7.09 & 6.76 & 4.88 & 8.46 \\
\hline
\end{tabular}




\begin{tabular}{|c|c|c|c|c|c|c|c|c|}
\hline \multirow{2}{*}{\begin{tabular}{|l|} 
Locations \\
Sample no.
\end{tabular}} & \multicolumn{4}{|c|}{ Southern Tianshan } & \multicolumn{4}{|l|}{ Bogda } \\
\hline & 1 & 5 & 16-6 & 29-12 & 2961 & 2962 & 302 & 2989 \\
\hline Age & $298 \mathrm{Ma}$ & $284 \mathrm{Ma}$ & 280-270 Ma & $264 \mathrm{Ma}$ & P1 & P1 & 289 Ма & P1 \\
\hline Rocks & Granodiorite & Porphyritic granite & Two-mica granite & Alkali feldspar granite & Basalt & Basalt & Dacite dyke & Rhyolite \\
\hline References & \multicolumn{4}{|c|}{ Jiang et al. (1999) } & \multicolumn{4}{|c|}{ Shu et al. (2005) } \\
\hline $\mathrm{Tb}$ & 0.95 & 1.5 & 0.32 & 0.25 & 0.95 & 0.87 & 0.62 & 1.61 \\
\hline Dy & 11.32 & 34.84 & 6.26 & 10.45 & 6.02 & 5.55 & 3.79 & 8.72 \\
\hline Ho & 0.72 & 1.7 & 0.5 & 1.5 & 1.49 & 1.27 & 0.84 & 2.12 \\
\hline Er & 1.87 & 4.48 & 1.51 & 4.07 & 3.38 & 3.15 & 2.39 & 5.73 \\
\hline $\mathrm{Tm}$ & 0.27 & 0.7 & 0.2 & 0.63 & 0.59 & 0.56 & 0.35 & 1.11 \\
\hline $\mathrm{Yb}$ & 1.69 & 4.44 & 1.47 & 4.14 & 3.68 & 3.35 & 2.27 & 5.47 \\
\hline $\mathrm{Lu}$ & 0.23 & 0.8 & 0.22 & 0.73 & 0.43 & 0.44 & 0.33 & 0.63 \\
\hline$\Sigma$ REE & 343.71 & 432.35 & 38.46 & 151.76 & 144.5 & 140.2 & 105.93 & 205.48 \\
\hline$(\mathrm{La} / \mathrm{Yb})_{N}$ & 34.62 & 11.05 & 2.80 & 3.90 & 4.8 & 5.2 & 5.9 & 4.5 \\
\hline$\delta \mathrm{Eu}$ & 0.76 & 0.06 & 0.98 & 0.15 & 1.03 & 0.99 & 1.02 & 0.39 \\
\hline V & - & - & - & - & - & - & - & - \\
\hline $\mathrm{Cr}$ & 17.8 & 22.04 & 22.59 & 21.04 & - & - & - & - \\
\hline $\mathrm{Co}$ & - & - & - & - & - & - & - & - \\
\hline $\mathrm{Ni}$ & 5.7 & 8.03 & 5.9 & 6.48 & - & - & - & - \\
\hline $\mathrm{Cu}$ & - & - & - & - & - & - & - & - \\
\hline $\mathrm{Zn}$ & - & - & - & - & - & - & - & - \\
\hline $\mathrm{Ga}$ & - & - & - & - & - & - & - & - \\
\hline $\mathrm{Ge}$ & - & - & - & - & - & - & - & - \\
\hline $\mathrm{Rb}$ & 91.6 & 179.56 & 142.76 & 246.59 & - & - & - & - \\
\hline
\end{tabular}




\begin{tabular}{|c|c|c|c|c|c|c|c|c|}
\hline \multirow{2}{*}{\begin{tabular}{|l} 
Locations \\
Sample no.
\end{tabular}} & \multicolumn{4}{|c|}{ Southern Tianshan } & \multicolumn{4}{|l|}{ Bogda } \\
\hline & 1 & 5 & $16-6$ & 29-12 & 2961 & 2962 & 302 & 2989 \\
\hline Age & $298 \mathrm{Ma}$ & $284 \mathrm{Ma}$ & $280-270 \mathrm{Ma}$ & $264 \mathrm{Ma}$ & P1 & P1 & $289 \mathrm{Ma}$ & P1 \\
\hline Rocks & Granodiorite & Porphyritic granite & Two-mica granite & Alkali feldspar granite & Basalt & Basalt & Dacite dyke & Rhyolite \\
\hline References & \multicolumn{4}{|c|}{ Jiang et al. (1999) } & \multicolumn{4}{|c|}{ Shu et al. (2005) } \\
\hline $\mathrm{Sr}$ & 396.7 & 154.42 & 87.67 & 52.8 & - & - & - & - \\
\hline Y & 15.28 & 54.64 & 12.43 & 39.18 & 25.48 & 24.86 & 21.35 & 41.22 \\
\hline $\mathrm{Zr}$ & 65.87 & 303.06 & 39.48 & 83.97 & - & - & - & - \\
\hline $\mathrm{Nb}$ & 14.27 & 20.13 & 8.11 & 23.79 & - & - & - & - \\
\hline $\mathrm{Cs}$ & 2.87 & 5.89 & 4.1 & 3.25 & - & - & - & - \\
\hline $\mathrm{Ba}$ & 1197 & 623.9 & 295.08 & 70.4 & - & - & - & - \\
\hline Hf & 2.11 & 8.23 & 1.5 & 4.18 & - & - & - & - \\
\hline $\mathrm{Ta}$ & 0.73 & 2.09 & 0.46 & 2.03 & - & - & - & - \\
\hline Th & 31.88 & 33.18 & 13.02 & 50.25 & - & - & - & - \\
\hline $\mathrm{Pb}$ & 34.48 & 40.6 & 40.74 & 38.32 & - & - & - & - \\
\hline $\mathrm{U}$ & 3.45 & 3.73 & 1.81 & 8.13 & - & - & - & - \\
\hline $\mathrm{Th} / \mathrm{Ta}$ & 43.671 & 15.8755981 & 28.30434783 & 24.7537 & - & - & - & - \\
\hline $\mathrm{Ce} / \mathrm{Pb}$ & 4.38 & 3.37 & 0.31 & 1.50 & - & - & - & - \\
\hline $\mathrm{Nb} / \mathrm{La}$ & 0.17 & 0.29 & 1.41 & 1.06 & - & - & - & - \\
\hline $\mathrm{Th} / \mathrm{La}$ & 0.39 & 0.49 & 2.27 & 2.23 & - & - & - & - \\
\hline
\end{tabular}

ALK (all alkaline) $=\mathrm{Na}_{2} \mathrm{O}+\mathrm{K}_{2} \mathrm{O}$, ASI (alumina saturation index $)=$ molar $\mathrm{Al}_{2} \mathrm{O}_{3} /\left(\mathrm{Na}_{2} \mathrm{O}+\mathrm{K}_{2} \mathrm{O}+\mathrm{CaO}\right), \Sigma R E E$ total rare earth elements, $\delta$ Eu$($ Eu anomaly $)=\mathrm{Eu}_{N} \times 2 /\left(\mathrm{Sm}_{\mathrm{N}}+\mathrm{Gd}_{N}\right)$, subscript $N$ refers to chondrite normalized value 